Review

\title{
Trade in live reptiles, its impact on wild populations, and the role of the European market
}

\author{
Mark Auliya a,*, Sandra Altherr ${ }^{\text {b }}$, Daniel Ariano-Sanchez ${ }^{c}$, Ernst H. Baard ${ }^{\text {d }}$, Carl Brown ${ }^{\text {d }}$, Rafe M. Brown ${ }^{\text {e, }}$
} Juan-Carlos Cantu ${ }^{\mathrm{f}}$, Gabriele Gentile ${ }^{\mathrm{g}}$, Paul Gildenhuys ${ }^{\mathrm{d}}$, Evert Henningheim ${ }^{\mathrm{h}}$, Jürgen Hintzmann ${ }^{\mathrm{i}}$, Kahoru Kanari ${ }^{j}$, Milivoje Krvavac ${ }^{k}$, Marieke Lettink ${ }^{1}$, Jörg Lippert ${ }^{m}$, Luca Luiselli ${ }^{n, o}$, Göran Nilson ${ }^{p}$, Truong Quang Nguyen ${ }^{\mathrm{q}}$, Vincent Nijman ${ }^{\mathrm{r}}$, James F. Parham ${ }^{\mathrm{s}}$, Stesha A. Pasachnik ${ }^{\mathrm{t}}$, Miguel Pedrono ${ }^{\mathrm{u}}$, Anna Rauhaus v, Danny Rueda Córdova ${ }^{\text {w }}$, Maria-Elena Sanchez ${ }^{\mathrm{x}}$, Ulrich Schepp ${ }^{\mathrm{y}}$, Mona van Schingen ${ }^{\mathrm{z}, \mathrm{v}}$, Norbert Schneeweiss ${ }^{\text {aa }}$, Gabriel H. Segniagbeto ${ }^{\mathrm{ab}}$, Ruchira Somaweera ${ }^{\mathrm{ac}}$, Emerson Y. Sy ${ }^{\text {ad }}$, Oguz Türkozan ${ }^{\text {ae }}$, Sabine Vinke ${ }^{\text {af }}$, Thomas Vinke ${ }^{\text {af }}$, Raju Vyas ${ }^{\text {ag }}$, Stuart Williamson ${ }^{\text {ah, } 1}$, Thomas Ziegler ${ }^{\text {ai,aj }}$

a Department Conservation Biology, Helmholtz Centre for Environmental Conservation (UFZ), Permoserstrasse 15, 04318 Leipzig, Germany

b Pro Wildife, Kidlerstrasse 2, 81371 Munich, Germany

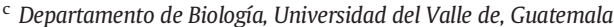

d Western Cape Nature Conservation Board, South Africa

e Department of Ecology and Evolutionary Biology,University of Kansas Biodiversity Institute, 1345 Jayhawk Blvd, Lawrence, KS 66045, USA

${ }^{\mathrm{f}}$ Bosques de Cerezos 112, C.P. 11700 México D.F., Mexico

g Dipartimento di Biologia, Universitá Tor Vergata, Roma, Italy

${ }^{\text {h }}$ Amsterdam, The Netherlands

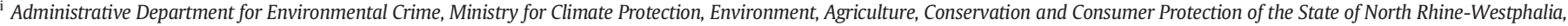
Schwannstrasse 3, 40476 Düsseldorf, Germany

${ }^{j}$ United Nations University, Institute for the Advanced Study of Sustainability, Shibuya-ku, Tokyo 150-8925, Japan

${ }^{\mathrm{k}}$ Institute for Nature Conservation, Dr Ivana Ribara 91, 11070 Belgrade, Serbia

${ }^{1}$ Fauna Finders, Corsair Bay, Lyttelton 8082, New Zealand

${ }^{m}$ Department of Nature Conservation, Ministry of Rural Development, Environment and Agriculture of the Federal State of Brandenburg, Germany

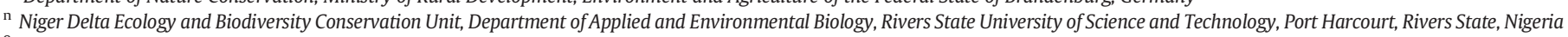

${ }^{0}$ Environmental Studies Centre Demetra, via Olona 7, 00198 Rome, Italy

P Institutt for Biovitenskap, Kristine Bonnevies hus, Blindernvn. 31, 0371 Oslo, Norway

${ }^{\mathrm{q}}$ Institute of Ecology and Biological Resources, Vietnam Academy of Science and Technology, 18 Hoang Quoc Viet Road, Hanoi, Viet Nam

${ }^{r}$ Department of Social Sciences, Oxford Brookes University, Headington Campus, Oxford OX3 OBP, United Kingdom

s John D. Cooper Archaeological and Paleontological Center, Department of Geological Sciences, California State University, Fullerton, 800 N State College Boulevard, Fullerton, CA, USA

t San Diego Zoo Institute for Conservation Research, 15600 San Pasqual Valley Rd, Escondido, CA, 92027

u CIRAD, UPR AGIRs, Ampandrianomby, B.P. 853, 101 Antananarivo, Madagascar

v Cologne Zoo, Riehler Strasse 173, 50735, Cologne, Germany

w Dirección del Parque Nacional Galápagos, Santa Cruz, Puerto Ayora, Ecuador

${ }^{x}$ Bosques de Cerezos 112, C.P. 11700 México D.F., Mexico

y Schlehenweg 2, 53177 Bonn, Germany

${ }^{z}$ Department of Terrestrial Ecology, Zoological Institute, Cologne University, Zülpicher Strasse 47b, 50674 Cologne, Germany

aa Landesamt für Umwelt, Gesundheit und Verbraucherschutz, Naturschutzstation Rhinluch, Nauener Str. 68, D-16833 Linum, Germany

ab University of Lomé, Faculty of Sciences, Department of Zoology, BP: 6057 Lomé, Togo

ac Biological Environmental Survey, North Perth, WA 6006, Australia

ad Philippine Center for Terrestrial and Aquatic Research, 1198 Benavidez St., \#1202 Tondo, Manila, Philippines

ae Adnan Menderes University, Faculty of Science and Arts, Department of Biology, Aydin, Turkey

af Paraguay Salvaje, Filadelfia 853, 9300 Fernheim, Paraguay

ag Sayaji Zoo, Vadodara, Gujarat, India

\footnotetext{
* Corresponding author.

E-mail addresses: mark.auliya@ufz.de (M. Auliya), Sandra.Altherr@prowildlife.de (S. Altherr), dariano@uvg.edu.gt (D. Ariano-Sanchez), ebaard@capenature.co.za (E.H. Baard), cbrown@capenature.co.za (C. Brown), rafe@ku.edu (R.M. Brown), jccantu1@gmail.com (J.-C.Cantu), gabriele.gentile@uniroma2.it (G. Gentile), pgilden@kingsley.co.za (P. Gildenhuys), evert.henningheim@sdgl.org (E. Henningheim), Juergen.Hintzmann@mkulnv.nrw.de (J. Hintzmann), kahoru.kanari@gmail.com (K. Kanari), milivoje.krvavac@zzps.rs (M. Krvavac), marieke_kakariki@clear.net.nz (M. Lettink), Joerg.Lippert@LUGV.Brandenburg.de (J. Lippert), lucamlu@tin.it (L. Luiselli), goran.nilson@vgregion.se (G. Nilson), vnijman@brookes.ac.uk (V. Nijman), jparham@fullerton.edu (J.F. Parham), sapasachnik@gmail.com (S.A. Pasachnik), pedrono@cirad.fr (M. Pedrono), anna-rauhaus@t-online.de (A. Rauhaus), drueda@galapagos.gob.ec (D.R. Córdova), teyeliz@gmail.com (M.-E. Sanchez), UlrichSchepp@gmx.net (U. Schepp), Mschinge@smail.uni-koeln.de (M. van Schingen), norbert.schneeweiss@lugv.brandenburg.de (N. Schneeweiss),gsegniagbeto@gmail.com (G.H. Segniagbeto), ruchira.somaweera@gmail.com (R. Somaweera),emerson.sy@gmail.com (E.Y.Sy), oguz.turkozan@gmail.com (O. Türkozan), s-t-vinke@gmx.de (S.Vinke), s-t-vinke@gmx.de (T. Vinke), razoovyas@hotmail.com (R. Vyas), Stuart.Williamson@mpi.govt.nz (S. Williamson), ziegler@koelnerzoo.de (T. Ziegler).

${ }^{1}$ Current address: Ministry of Primary Industries, Auckland, New Zealand.
} 
ah Department of Conservation Auckland Conservancy Office, Auckland 1145, New Zealand

ai Biodiversity and Nature Conservation Projects Vietnam and Laos, Cologne Zoo, Riehler Strasse 173, 50735 Cologne, Germany

aj Zoological Institute, Cologne University, Zülpicher Strasse 47b, 50674 Cologne, Germany

\section{A R T I C L E I N F O}

\section{Article history:}

Received 18 December 2015

Received in revised form 18 May 2016

Accepted 24 May 2016

Available online $\mathrm{xxx}$

\section{Keywords:}

European Union

Illegal

International law

Over-exploitation

Pet trade

Reptile diversity

\begin{abstract}
A B S T R A C T
Of the 10,272 currently recognized reptile species, the trade of fewer than $8 \%$ are regulated by the Convention on International Trade in Endangered Species of Wild Fauna and Flora (CITES) and the European Wildlife Trade Regulations (EWTR). However, the International Union for Conservation of Nature (IUCN) Red List has assessed 45\% of the world's reptile species and determined that at least 1390 species are threatened by "biological resource use". Of these, 355 species are intentionally targeted by collectors, including 194 non-CITES-listed species. Herein we review the global reptile pet trade, its impacts, and its contribution to the over-harvesting of species and populations, in light of current international law. Findings are based on an examination of relevant professional observations, online sources, and literature (e.g., applicable policies, taxonomy [reptile database], trade statistics [EUROSTAT], and conservation status [IUCN Red List]). Case studies are presented from the following countries and regions: Australia, Central America, China, Galapagos Islands (Ecuador), Germany, Europe, India, Indonesia (Kalimantan), Islamic Republic of Iran, Japan, Madagascar, Mexico, New Zealand, the Philippines, South Africa, Sri Lanka, Vietnam, Western Africa, and Western Asia. The European Union (EU) plays a major role in reptile trade. Between 2004 and 2014 (the period under study), the EU member states officially reported the import of 20,788,747 live reptiles. This review suggests that illegal trade activities involve species regulated under CITES, as well as species that are not CITES-regulated but nationally protected in their country of origin and often openly offered for sale in the EU. Further, these case studies demonstrate that regulations and enforcement in several countries are inadequate to prevent the overexploitation of species and to halt illegal trade activities.
\end{abstract} (c) 2016 Elsevier Ltd. All rights reserved.

\section{Contents}

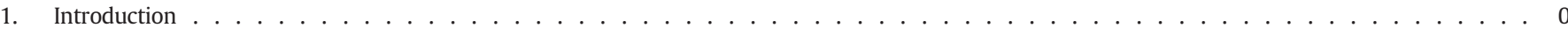

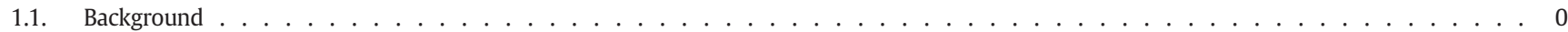

1.2. Global reptile diversity and international legal frameworks . . . . . . . . . . . . . . . . . . . . . . . . . 0

1.3. EU imports of live reptiles over the last decade . . . . . . . . . . . . . . . . . . . . . . . . . . . . . . . . . . 0

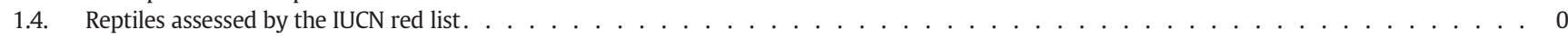

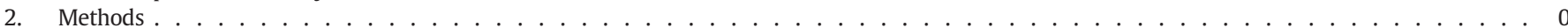

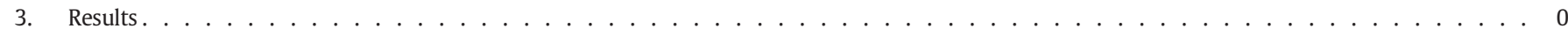

3.1. Legal but unregulated trade . . . . . . . . . . . . . . . . . . . . . . . . . . . . . . . 0

3.1.1. Exploitation of threatened non-CITES species . . . . . . . . . . . . . . . . . . . . . . . 0

3.1.2. Exploitation of newly discovered or rediscovered species. . . . . . . . . . . . . . . . . . . . . . . . . . 0

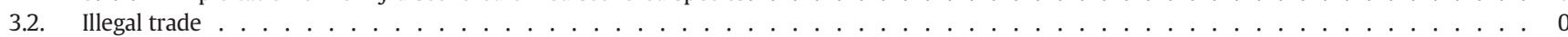

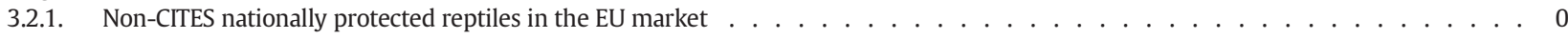

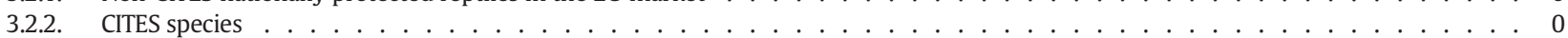

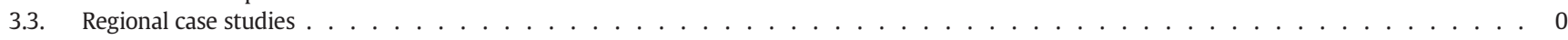

3.3.1. Europe, Middle East and Central Asia . . . . . . . . . . . . . . . . . . . . . . . . . . . 0

3.3.2. Africa and Madagascar . . . . . . . . . . . . . . . . . . . . . . . . . . . . . . . . . . . . . . . . . . . . . . 0

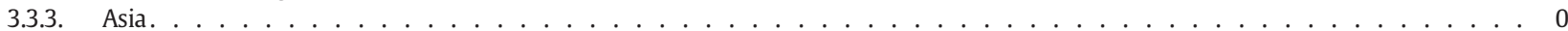

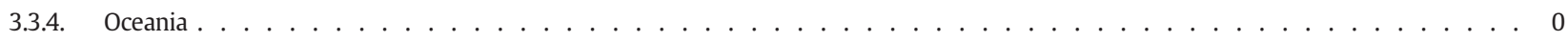

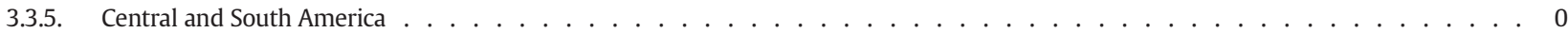

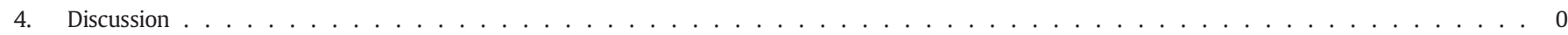

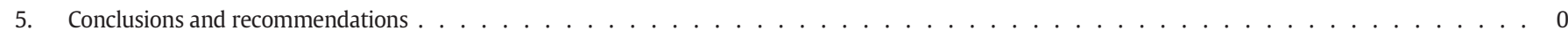

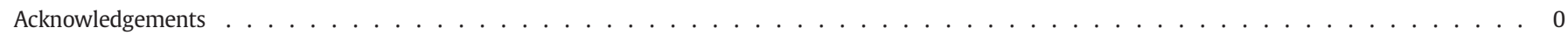

References. $\ldots$

\section{Introduction}

\subsection{Background}

The concept of species conservation has been complemented by broader approaches to environmental challenges, such as the controversial "ecosystem services" concept (Costanza et al., 1997; Adams, 2014). However, in view of the increasing numbers of globally threatened species (IUCN, 2015), the protection and sustainable conservation of species demands more attention than ever (Pimm et al., 1995; Dirzo and Raven, 2003; Ceballos et al., 2015). Despite comprehensive efforts to prevent biodiversity loss (Proença and Pereira, 2013), success has been limited, as the decline and extinction of species is generally the result of a combination of synergistic processes (Brook et al., 2008;
Crandall, 2009). Lenzen et al. (2012) linked biodiversity loss to the increased cultivation and export of agricultural products in tropical regions, identifying top foreign consumers as responsible for the decline of species. However, other anthropogenic threats contribute to direct and abrupt population declines, which may decimate species in otherwise intact habitats. For example, the targeted harvest and trade in species that have economic value in both the country of origin and the country of import is an immense threat (TRAFFIC, 2008).

Collection of targeted species occurs both legally and illegally (Rosen and Smith, 2010). Demand for rare species stimulates illegal trade (Courchamp et al., 2006; Wyler and Sheikh, 2013), which ultimately can lead to the over-harvesting of those species (Cooney et al., 2015). Although determining reliable figures is difficult, given the nature of illicit activities, the value of the legal and illegal wildlife trade has been 
estimated to be US\$20 billion (Wyler and Sheikh, 2013) to US\$323 billion (TRAFFIC, 2014). In 2008, the black market in wildlife trade was estimated to be the fourth most lucrative crime after trafficking in drugs, arms, and human beings (TRAFFIC, 2008).

The over-exploitation of reptiles in the pet trade has been discussed since the late 1960s (Lambert, 1969; Spellerberg, 1976). More recent studies have addressed the unsustainable exploitation of additional reptile species (Gibbons et al., 2000; Schlaepfer et al., 2005) and reported that intentional harvest is the second largest threat to the survival of many reptile species (Böhm et al., 2013). Popular literature has even profiled illegal reptile trade activities, its scope, and the people involved (Christy, 2008; Smith, 2011). Reptiles currently represent the second most species-rich vertebrate class after birds in the international pet trade (Bush et al., 2014). Engler and Parry-Jones (2007) stated that in 2005, the European Union (EU) was the top global importer by value of live reptiles for the pet trade (valued at $€ 7$ million) and reptile skins (valued at $€ 100$ million). In quantity the EU ranks second (18.2\%) after the United States (56.1\%) in live reptile imports (Robinson et al., 2015).

Species extinction processes that are causally linked to trade activities remain relatively undocumented (Jenkins et al., 2014). However, it is evident that certain species are particularly vulnerable to over-collection, such as long-lived species with long generation times, those with low fecundity, (e.g., tortoises and large lizards) (Reznick et al., 2002; Baling et al., 2013), and species that are rare and endemic to islands and specific habitats (Webb et al., 2002). The IUCN Red List assessments provide a summary of the current species status based on expert knowledge. However, the IUCN faces many challenges in these efforts as it is in large part a volunteer based organization, thus these assessments are at times out of date (e.g., Brown et al., 2013; Siler et al., 2012). Further, re-assessments of many species are carried out infrequently, resulting in many countries, such as the Philippines, remaining behind in updating the conservation status of species (e.g., Brown et al., 2013; Siler et al., 2012), including information on taxonomy and genetics (e.g., Siler et al., 2011, 2014). Nevertheless these assessments provide the best documentation of the status of species and changes therein. These species classifications, however, do not necessarily translate to national or international protection and species not assessed by the IUCN Red List may also be threatened. Formal protection must be achieved by additional entities. The information within the Red List assessments can aid in this effort by increasing capacity and reducing uncertainty in species' knowledge (see Hoffmann et al., 2008), but it is international Conventions that must create appropriate regulations and national authorities that must enforce them. Below we present an overview of the current status of reptiles, the various ways in which reptiles are traded, and the applicable regulations.

\subsection{Global reptile diversity and international legal frameworks}

As of August 2015, a total of 10,272 species of reptiles have been described: 193 amphisbaenians (Amphisbaenia), 6145 lizards (Sauria), 3567 snakes (Serpentes), 341 turtles (Testudines), 25 crocodilians (Crocodylia), and one tuatara (Rhynchocephalia) (Uetz and Hošek, 2015).

The Convention on International Trade in Endangered Species of Wild Fauna and Flora (CITES) was enacted in 1975 and regulates the international trade in threatened and potentially threatened species (live specimens, parts, or derived products) to prevent over-exploitation and thereby ensure legal, sustainable, and traceable trade. The convention is implemented through an export and import control licensing system, to which currently 182 parties, including the EU, are bound. This system monitors trade in $>35.000$ species of flora and fauna (of which 793 are reptile species). These species are listed in three Appendices (see below), each having various prerequisites that underpin permitting trade.

Appendix I: lists species threatened with extinction; commercial trade is not permitted; presently 80 reptile species are included (https://www.cites.org/sites/default/files/eng/disc/species_02.10.2013. pdf - accessed 21 November 2015).

Appendix II: lists species that may become threatened with extinction, in case international trade is not regulated; trade is permitted in accordance with an export permit; however a trade in App. II species needs to ensure that such export will not be detrimental to the survival of that species (https://www.cites.org/eng/disc/text.php\#IV - accessed 21 November 2015); presently 673 reptile species are included (see above source).

Appendix III: lists species that are currently being monitored in a given country that needs help to protect from over-harvesting; trade in these species is allowed following proper permitting; 40 reptile species at present are included (see above source).

Every two to three years there is an opportunity for CITES Parties to submit proposals for adding, removing, or transferring species in the Appendices. While consensus on these proposals is sought, many decisions are made by vote. The international role of CITES is to ensure that international trade in specimens of wild animals and plants does not threaten their survival, and, thus, the convention is positioned at the interface of biodiversity and trade interests (https://www.cites.org - accessed 20 November 2015).

The EU implements CITES via the European Wildlife Trade Regulations (EWTR), which includes additional control mechanisms, for example the suspension of imports of wild-sourced species (http://eur-lex. europa.eu/legal-content/EN/TXT/PDF/?uri=CELEX:

32015R0736andfrom =EN - accessed, 21 Nov. 2015). The three CITES Appendices are roughly aligned to the EWTR Annexes A-C. One nonCITES reptile species is listed in EWTR Annex A (Latifi's viper (Montivipera [Vipera] latifii) (Section 3.3.1)), and five in Annex B (e.g., the turquoise dwarf gecko [Lygodactylus williamsi] [see Section 3.2.1]). In addition, 23 non-CITES species are included in Annex D, which is a monitoring list to ensure sustainability, e.g., the five-keeled spinytailed iguana (Ctenosaura quinquecarinata) (http://eur-lex.europa.eu/ legal-content/EN/TXT/PDF/?uri=CELEX:32014R1320andfrom=EN accessed 21 November 2015).

With only $7.7 \%$ of the world's reptile species listed in the CITES Appendices and $7.9 \%$ listed in the EWTR Annexes, the vast majority (92\%) is not listed, and therefore trade in these species is not monitored or regulated at the international level, particularly within the EU.

\subsection{EU imports of live reptiles over the last decade}

Within the period 2004-2014, the EU member states officially reported the import of 20,788,747 live reptiles (CITES and non-CITES species) (Eurostat, 2015). With 6,101,040 live specimens, Germany was by far the largest importer within the EU, followed by Great Britain $(3,469,109)$, Spain $(2,912,171)$, Czech Republic $(1,899,420)$, and Italy $(1,780,546)$.

According to Eurostat (2015) the top 15 countries of origin for the EU live reptile imports are USA $(13,083,406$ specimens), China $(1,181,561)$, Vietnam $(1,038,065)$, Tanzania $(835,423)$, El Salvador (611,643), Togo $(570,475)$, Uzbekistan $(451,691)$, Ghana $(428,983)$, Indonesia $(407,214)$, Egypt $(351,176)$, Hong Kong $(176,986)$, Taiwan $(148,804)$, Madagascar $(113,626)$, Guyana $(90,964)$, and Benin $(87,333)$. Ten out of these 15 countries of origin are within biodiversity hotspots, indicating a high proportion of endemic and threatened species: Vietnam, Tanzania, El Salvador, Togo, Ghana, Indonesia, Hong Kong, Taiwan, Madagascar, and Benin (Myers et al., 2000).

\subsection{Reptiles assessed by the IUCN red list}

Forty-five percent $(n=4669)$ of the world's reptiles have been assessed for the IUCN Red List (IUCN, 2015); of these, 180 have been classified as Critically Endangered (CR), 361 as Endangered (EN), and 403 as Vulnerable (VU). Of those assessed, at least 1390 species are threatened by "biological resource use" either as a primary or contributing threat. Among these, $25 \%(n=355)$ of species are threatened by 
"intentional use (species is the target)" and 194 of these species (14\%) are not included in the CITES Appendices. Although some species are collected for other purposes (e.g., some Pythonidae spp., Varanidae spp. and Tupinambis spp. are harvested intensively for the leather industry), most species are in fact collected for the international pet trade. Further, many species known to be sought after in the international pet trade did not show up within the aforementioned query of the IUCN Red List as they have not yet been assessed, such as the Solomon island skink (Corucia zebrata) and caiman lizards (Dracaena spp.). Additional species affected by the international pet trade, such as the Philippine forest turtle (Siebenrockiella leytensis), the pancake tortoise (Malacochersus tornieri), or the Natal midlands dwarf chamaeleon (Bradypodion thamnobates), also did not appear in the query as their assessments are out of date as discussed above (see IUCN, 2015).

\section{Methods}

The primary methodological approach for this review was extensive, global-scale consultation with experts who have relevant, long-term experience addressing reptile trade issues. These experts include: scientists, officers of conservation agencies, conservationists, and enforcement and customs officials. Contributing authors provided examples of unsustainable and illegal trade activities regarding the collection of, and international trade in, live reptiles within their regions of expertise. This information was supported by a comprehensive review of the published literature as well as anecdotal unpublished information that was made available by relevant administrative bodies. Information available for non-CITES species in trade (e.g., Annex D species of the EWTR) was filtered from the IUCN Red List database. Additional data sources including grey literature, reptile fairs, wholesaler and retail shop lists, and species' lists of private collectors were included. Furthermore, data extracted from several online databases (see below) augmented the results and conclusions of this review:

- CITES Trade database (http://trade.cites.org/): Searches entered for all reptile taxa in Appendices I-III for the year range 2004-2014 using trade terms "live" and "eggs (live)" and the relevant taxa (genus or species). Queries were structured to capture data regarding major exporting and importing countries, species, quantities, and sources

- EU Wildlife Trade Regulations (EWTR): All reptile species listed in Annexes A-D. (http://eur-lex.europa.eu/legal-content/EN/TXT/PDF/? uri=CELEX:32014R1320andfrom $=E N$ - accessed 21 November 2015)

- IUCN Red List (http://www.iucnredlist.org): All reptile species listed in any of the threat categories (IUCN, 2015)

- The Reptile database (http://www.reptile-database.org/): this reference provided the taxonomy applied (Uetz and Hošek, 2015).

\section{Results}

\subsection{Legal but unregulated trade}

Rarity in the wild or limited availability in the pet market (e.g., remote or hard to access habitats, low export numbers) makes a species especially attractive to private collectors (Brook and Sodhi, 2006; Courchamp et al., 2006; Hall et al., 2008). Accordingly, some traders have specialized in species that are threatened, were only recently described, rediscovered, or are not yet scientifically described (see Section 3.1.2).

\subsubsection{Exploitation of threatened non-CITES species}

Species that are classified as threatened by the IUCN Red List or national Red Lists (http://www.nationalredlist.org/home/about/ accessed 1 April 2016) but are not yet covered by CITES are highly attractive for the international pet trade, especially those with distinct color patterns or special biological features. An analysis of non-CITES reptiles in the European pet trade with IUCN Red List status CR, EN, or VU resulted in 75 threatened species being identified for sale. Some of these non-CITES species are; however, nationally protected in their country of origin (see Section 3.2.1); others remain unprotected despite their precarious conservation status. Among these sought-after species are e.g., Orlov's viper (Vipera orlovi), CR and endemic to a small area in Caucasus, Russia, with $<250$ mature individuals left (Tuniyev et al., 2009a; Zazanashvili and Mallon, 2009); the party gecko (Paroedura lohatsara), CR and endemic to northern Madagascar (Raxworthy et al., 2011); the large-headed gecko (Paroedura masobe), EN and endemic to the north-eastern part of Madagascar (Rosa et al., 2011); the leopard fringe-fingered lizard (Acanthodactylus pardalis), VU and native to Egypt and Libya (Böhme and El Din, 2006); and a variety of geckos from New Caledonia, such as the live-bearing greater rough-snouted gecko (Rhacodactylus trachycephalus) (Bauer et al., 2012). Although Parker's snake-necked turtle (Chelodina parkeri) is classified by IUCN as VU and has only a limited distribution, Indonesia has set a collection quota of 150 specimens from West Papua and Papua each (Natusch and Lyons, 2012). This species is sold in Europe for approximately $€ 400$ each. For many other species, collections remain completely unregulated.

\subsubsection{Exploitation of newly discovered or rediscovered species}

Field herpetologists and conservationists are increasingly alarmed that type localities are used by commercial collectors to exploit these populations (Diesmos et al., 2004, 2012; Stuart et al., 2006; Menegon et al., 2011; Yaap et al., 2012). The examples are numerous and it is believed that reporting new locality records of threatened and highly demanded species could be considered detrimental to species survival (e.g., Grismer et al., 2008; Razafimahatratra et al., 2010).

In 2010, Grismer et al. (2010) described the new psychedelic gecko (Cnemaspis psychedelica) endemic to the $8 \mathrm{~km}^{2}$ island Hon Khoai in Vietnam. From 2013 onwards, this species has regularly been for sale in Europe, for approximately €2500-3000/pair (Altherr, 2014; see Section 3.3.3). Likewise, in 2012, Yaap et al. published details of the first evidence of the Borneo earless monitor lizard (Lanthanotus borneensis) in West Kalimantan. Shortly thereafter, dozens of $L$. borneensis were offered by traders from the Czech Republic and Germany (see Section 3.3.3). The description of Varanus bitatawa (Welton et al., 2010) was soon followed by reports of specimens offered in the pet trade, which were caught in violation of the Philippines' Wildlife Act (Sy, 2012). Most strikingly, the rare colubrid snake Archelaphe bella chapaensis had not been seen in Vietnam since its description in the 1930s and was thought to be extinct. In 2010, the species was re-discovered in northern Vietnam (Orlov et al., 2010). One year later, online advertisements were offering "farmed" specimens from Vietnam, with prices up to $€ 1650 /$ pair. Likewise the rediscoveries of Campbell's alligator lizard (Abronia campbelli) in 2009 (Ariano-Sánchez and TorresAlmazán, 2010) and S. leytensis in 2004, resulted in intense poaching for the international pet trade (see Sections 3.3.5 and 3.3.3, respectively). Meijaard and Nijman (2014) outlined how publicity of rediscoveries through scientific and public media can have a detrimental effect on the species. According to Stuart et al. (2006), immediately after being described, both the Roti island snake-necked turtle (Chelodina mccordi), and the gecko Goniurosaurus luii from south-eastern China became recognized as rarities in the international pet trade, with a market price of about $€ 1500$ each. They became so heavily collected that currently $C$. mccordi is nearly extinct in the wild (Shepherd and Ibarrondo, 2005) and $G$. luii has been extirpated from its type locality (Grismer et al., 1999). Given the risk of illegal collecting and trade, scientists refrained from publishing locality records of two new Goniurosaurus species (Yang and Chan, 2015). Matilda's horned viper (Atheris matildae), a rare arboreal snake from the Tanzanian southern highlands was described by Menegon et al. (2011). To avoid over-exploitation scientists withheld precise locality information; however, the species was offered by Austrian and Serbian citizens for approximately €500/specimen within the same year. Indeed, even with the concealment of the type 
locality (e.g., Nilson et al., 1990) taxa are being exploited due to the immense interest in these species, and a lack of national and international law (Türkozan in litt. to Stuart, in litt. to Auliya, Oct. 2011).

\subsection{Illegal trade}

Reptile trafficking affects both CITES-protected species and species that are protected only at the national level in their range state or country.

\subsubsection{Non-CITES nationally protected reptiles in the EU market}

The EU's regulation on wildlife trade (Council Regulation [EC] No. 338/97) essentially implements the protection of species native to the EU or listed by CITES. All other species can be freely traded within the EU - whether they are threatened or strictly protected in their native range. An analysis by Altherr (2014) documented that the most expensive species are among those that are not CITES-listed but are protected by national law in their country of origin, resulting in low abundance in trade and fueling market prices. Those species may fetch prices of up to thousands of Euro/pair. Some traders specialize in the sale of such species because the profit margin is high, similar to some CITES species; however, there is no legal risk once the animals are in the EU, to openly offer them for sale. Among such cases are agamids from Sri Lanka (see Section 3.3.3), the Borneo earless monitor lizard (Lanthanotus borneensis) (see Section 3.3.3), arboreal alligator lizards (Abronia) from Guatemala (Section 3.3.5), spiny-tailed iguanas (Ctenosaura), four-toed worm lizards (Bipes canaliculatus) endemic to Mexico (see Section 3.3.5), Brazilian galliwasps (Diploglossus lessonae), as well as thorny devils (Moloch horridus) and shingleback lizards (Tiliqua rugosa) endemic to Australia (Section 3.3.4), South African adders (Bitis spp.) (Warner, 2009), and Okinawan ground geckos (Goniurosaurus kuroiwae) endemic to the Ryukyu Archipelago in Japan (Altherr, 2014).

One well-documented case is Lygodactylus williamsi. This species is IUCN Red Listed as CR and has an Area of Occupancy of only $8 \mathrm{~km}^{2}$ in Tanzania. According to officials of the Tanzania Wildlife Research Institute, neither collection nor export of this species has ever been authorized, but specimens are often exported by intentional mislabelling or intermixed with unprotected geckos (Flecks et al., 2012). It is estimated that within a 4.5-year period (Dec 2004-Jul 2009) approximately 40,000 specimens were collected for the pet trade, resulting in a severely depleted population (Flecks et al., 2012). After four years of internal debate, the EU as the main destination finally included $L$. williamsi within its Annex B.

\subsubsection{CITES species}

Although CITES is a powerful tool to reduce or even ban the international trade of threatened species, there are, of course, several criminal ways to circumvent law. Export quotas (see https://www.cites.org/ eng/resources/quotas/index.php - accessed 1 April 2016), may be systematically exceeded as has been documented for several tortoise species from Indonesia (Shepherd and Nijman, 2007), the graceful chameleon (Chamaeleo gracilis) from Togo, the Usambara three-horned chameleon (Trioceros deremensis) from Tanzania, and the savannah monitor (Varanus exanthematicus) from Benin (UNEP-WCMC, 2010). Paperwork is also often manipulated such that CITES-protected species are mislabelled as unprotected species. For example, the rosette-nosed pygmy chameleon (Rhampholeon spinosus) from Tanzania is classified by IUCN Red List as EN (Tolley and Menegon, 2014). This is the only species of its genus listed within CITES yet it is exported by the hundreds or even thousands, in shipments of "assorted pygmy chameleons" without proper or correct documentation (Anderson, 2014).

A widespread method of evading CITES regulations is camouflaging illegally wild-caught individuals with fraudulent labelling indicating that they have been captive-bred. Thus, there is growing and strong evidence that some countries appear to not be upholding their specific commitments under CITES and exercise laundering through commercial breeding farms (see Shi et al., 2007; Nijman and Shepherd, 2009; Lyons and Natusch, 2011; D'Cruze et al., 2015). This is evident by the fact that there are serious discrepancies between the numbers of reptiles exported to the EU that are declared as captive-bred and the numbers of reptiles that breeding facilities are actually producing or have the capacity to produce. Several Philippine species, such as varanids (Varanus olivaceus, V. bitatawa, V. cumingi), the Philippine cobra (Naja philippinensis), and turtles (S. leytensis, Cuora amboinensis), are a prime example of this. In one case, involving $V$. olivaceus, a private zoo owner in the Philippines substantiated his claim of captive breeding success (to apply for Philippine government CITES export permits) to legally export the species to the USA (Lutz, 2006). However, according to Bennett (2014) hard evidence of captive breeding could not be provided. Private zoological parks in the Philippines are claiming wildcaught specimens as captive bred in their facilities. One such facility claimed to have bred $>100$ S. leytensis without any evidence (e.g., broken egg shells, photographs of hatchling with egg yolk still attached) (Sy, 2014) (see Section 3.3.3).

A survey by Nijman and Shepherd (2009) found that all specimens of the emerald tree monitor (Varanus prasinus) and Timor monitor (Varanus timorensis) exported by Indonesia in 2006 as captive-bred were in fact wild-caught. According to field data collected between 2009 and 2011, Lyons and Natusch (2011) suggested that 80\% of green tree pythons (Morelia viridis) exported by Indonesia claimed as captive-bred were in fact from the wild. Large-scale laundering of this kind has also been documented for Madagascan chameleons, which were channelled via Lebanon and Kazakhstan to escape quotas for wild-caught specimens and temporary trade suspensions (Todd, 2011). Additional examples include the Princely spiny-tailed lizard (Uromastyx princeps) and the Omani spiny-tailed lizard (Uromastyx thomasi), both listed under CITES Appendix II since 1977. Uromastyx princeps has never been officially exported from its range countries (Somalia, Ethiopia and possibly Kenya); however, since 2008 specimens were exported as "captive-bred" from Mali and Switzerland. The only official export of $U$. thomasi from its sole range state Oman was in 2008, but those eight wild-caught individuals were re-labelled in Mali as "captive-bred" and re-exported to Austria the same year (UNEPWCMC, 2015).

In other instances, smugglers bypass CITES permitting and conceal reptiles on their bodies, in suitcases, or in parcels (e.g., Rosen and Smith, 2010; Herbig, 2011). In September 2007, a US citizen was arrested for smuggling three Fiji banded iguanas (Brachylophus bulabula) in his prosthetic leg. He told investigators that he had previously sold this type of iguana for several thousand Euros. In September 2015, a Mexican citizen was arrested in the Galapagos Islands for attempting to smuggle eleven endemic land and marine iguanas, listed in CITES App. II, with an estimated black market price of several thousand Euro each, on his body (see Section 3.3.5). The use of "hired tourists," as couriers for smuggling reptiles across borders is similarly common. In February 2014, British custom authorities arrested two young Romanian women with thirteen Bahamas rock iguanas (Cyclura rileyi) in their suitcases. The women were only engaged as couriers and, when questioned by authorities, named a Swiss man, who had paid for their trip (Perry, 2014). The black market value of $C$. rileyi, listed in CITES Appendix I, was estimated to be several thousand Euros each. According to the Bahamas CITES Authorities, the illegal export of these CR species to Western Europe had already been successful, and specimens in Germany and Austria are likely of illegal origin (Bahamas, 2014). Nevertheless, claimed offspring from these smuggled founders have received CITES export permits from European countries, and there are strong suspicions that these original animals are being used as cover to obtain CITES permits for newly smuggled animals and thus laundering new individuals of the same species (Bahamas, 2014). These examples demonstrate that if a highly lucrative species is involved, any strategy is applied to circumvent national and international law. 
The main objectives of this review are to illustrate the scope of international pet trade in reptiles, document the current policies and assess its efficacy, and substantiate claims that over-exploitation and illegal trade activities are widespread globally. Further, this review is intended to inform policy makers that the targeted unsustainable legal and illegal trade in numerous reptile species poses a considerable threat to biodiversity and proper ecosystem functioning in many of the world's most biodiverse countries, megadiverse nations, and global biodiversity conservation hotspots (e.g., Mittermeier et al., 1998; Mittermeier and Mittermeier, 2004).

\subsection{Regional case studies}

In the following sections, case studies are summarized by geographic location. As a result of trade dynamics, and the varying levels of implementation, enforcement, and policy among regions, there is substantial heterogeneity in the data available rendering these case studies variable and complex.

\subsubsection{Europe, Middle East and Central Asia}

Distinguishing between and enforcing regulations pertaining to captive bred, versus wild caught specimens in the trade remains a substantial challenge for enforcement officials. Information from Europe, Middle East and Central Asia demonstrates how national and international regulatory measures are inefficient to halt the illegal trade of threatened and endemic species.

German federal law on nature protection and the Species Conservation Act have prohibited the capture and husbandry of native amphibians and reptiles for almost 30 years. Nevertheless, the illegal trade of native reptiles is on-going and increasing. This correlated largely to a dramatic rise in reptile keeping in the 1980s, which was facilitated by the Internet and reptile trade fairs (Velo-Antón et al., 2011; Schneeweiss et al., 2014). This illegal trade has caused substantial declines, most likely in populations of European pond turtles (Emys orbicularis) and certainly in a population of European green lizards (Lacerta viridis). Between 2010 and 2011, three individuals responsible for the sale of $>10,000$ wild and native reptiles and amphibians since 1990 , were convicted, sentenced to probation and fined. Discrimination between legal captive-bred and illegal wild specimens remains difficult to effectively implement, and sale of these species is continuing and at times even promoted. In 2013, the German umbrella organization of pet shops (ZZF) portrayed E. orbicularis in a magazine as a suitable terrarium and outdoor species, without mentioning the precarious situation of the species in the wild and the threats caused by illegal collections (Anonymus, 2013). Due to the practical inability of enforcing the regulations, Schneeweiss et al. (2014) called for a complete ban on the trading of native amphibian and reptile species.

For decades the demand in live vipers for the pet trade has been established by a worldwide-specialized community (Auliya, 2003). Many European and central Asian vipers occur in small geographic areas, and this species group is distinctly threatened by the pet trade. There are a number of examples where skilful animal collectors remove the last few specimens of a locally threatened population or species. The IUCN Red List assessed nine European viper species that are partially threatened by the pet trade and two European viper species are regulated in CITES: Wagner viper (Montivipera wagneri) and the Meadow viper (Vipera ursinii).

Three species of vipers that have been particularly impacted by the pet trade: Montivipera latifi in the Alburz Mountains in Iran, M. wagneri in eastern Turkey, and the Caucasus viper (Vipera kaznakovi) (Tuniyev et al., 2009b). All three species are range-restricted, native to only small geographic areas in high mountain regions. While $M$. latifii was formerly over-exploited for its serum by the Hessarak Serum Institute in Iran, since 2014 it has been listed in Annex A of the EWTR (see above); however, it is still not listed on the Appendices of CITES. Montivipera latifii is not only illegally collected for domestic antivenin production but also collected for the international pet industry (Behrooz et al., 2015). Montivipera wagneri was depleted by the international pet trade (Nilson and Andrén, 1999), and, as a result, was listed in CITES Appendix II, in 1992. The situation is also very critical for the range-restricted $M$. albicornuta. This species is not present in any protected area, thus there is an urgent need to restrict or prevent the collection of this species for the pet trade (Nilson, 2009).

In terms of species richness and taxonomic diversity, Iran harbors one of the most remarkable reptile faunas within the western Palearctic region (Rastegar-Pouyani et al., 2015). In Iran, the illegal collection of herpetofauna for the national and international pet trade is a serious threat; of particular concern are the European pond turtle (Emys orbicularis), the Caspian turtle (Mauremys caspica) (Rastegar-Pouyani et al., 2015), and a variety of geckos. While Iranian leopard geckos (Eublepharis angramainyu) are native to Iran, Syria, Turkey, and Iraq, specimens in the European pet trade are often specified to originate from the Iranian Provinces of Khuzestan, Kermanshah, and Ilam. According to the Iranian CITES authorities, these geckos have been collected from Iranian provinces without permission (Mobaraki in litt. to Altherr, 2014). Depending on the intensity of the color pattern, specimens may fetch $€ 200-1000$ each. Traders selling these geckos in EU markets are from Austria, the Czech Republic, Ukraine, and the United Kingdom. Significant illegal trade for the international pet market is also well documented for the endemic Iranian Kaiser's mountain newt (Neurergus kaiseri) (Mobaraki et al., 2013).

\subsubsection{Africa and Madagascar}

The EU is one key player commercially exploiting reptile populations from western Africa. Members of almost all reptile groups from this region are harvested for the international pet trade. Trade dynamics in western Africa are complex, and illegal cross-border activities are prominent. In addition, the laundering of wild-caught animals, as captive bred or ranch stock is increasingly prominent. High endemism in reptile diversity is associated with increased illegal trade activities in this region. Micro-endemic species and populations have been detrimentally impacted by the international pet trade and national protection is insufficient to deter the international market, which is largely fuelled by smugglers. Information from this region demonstrates how endemic species are preferentially sought-after, resulting in severe declines from unsustainable commercial harvest.

The West African sub-region (mainly Benin, Togo, and Ghana) is recognized as the second most prolific reptile-exporting region in the world, after Central and South America (Harwood, 2003, http://trade. cites.org/ - accessed June 2014). Studies on the export patterns of these countries have been conducted by Buffrénil (1995), Jenkins (1998), Harris (2002), Harwood (2003), and Ineich (2006); and more recently Luiselli et al. (2012) studied trade dynamics of Pythonidae spp. Individuals from the EU, the USA, and Japan are key players in exploiting wild species from this area. Despite CITES regulatory measures the export of reptile species from western Africa remains prominent. Since 1990, Togo has been the world's leading exporter of the ball python (Python regius), resulting in 80,000 specimens being exported, during the period 2000-2010 (AFFO, 2001). This led CITES to impose an export quota for reptile species originating from Togo.

The most common species in this trade, destined for the international pet industry, are tortoises (e.g., Centrochelys sulcata, Kinixys nogueyi, K. erosa, K. homeana), aquatic turtles (e.g., Pelomedusa subrufa, Pelusios niger, P. castaneus, Trionyx triunguis), lizards (e.g., Chamaeleo gracilis, Chamaeleo senegalensis; Varanus exanthematicus, V. niloticus, V. ornatus), and snakes (Calabaria reinhardtii, Python regius and Python sebae). Other less common species in trade that have more unpredictable market demands include the puff adder (Bitis arietans), rhinoceros viper (Bitis nasicornis), fat-tail gecko (Hemitheconyx caudicinctus), West African carpet viper (Echis ocellatus), West African night adder (Causus maculatus), West African bush viper (Atheris chlorechis), western green mamba (Dendroaspis viridis), black-necked spitting cobra (Naja nigricollis), and Geyr's spiny-tailed lizard (Uromastyx geyri). We 
note that several of these species, whose distribution is Sahelian, such as the African spurred tortoise ( $C$. sulcata) and $U$. geyri, are consistently present in the Togo market, despite not occurring in Togo (Segniagbeto, 2009). This suggests that these, and possibly other species, are smuggled across weak country border controls that facilitate trafficking. For instance, local reptile farmers claim that many specimens, native to the "forest zone" and exported from Togo, Benin, and Ghana, are in fact from southern Nigeria. This is the case for the Home's hingeback tortoise (K. homeana) and the serrated hingeback tortoise ( $K$. erosa), both captured in the Cross River State (Nigeria) and exported from Benin.

Although regulated by quotas, the illegal cross-border trade remains a concern. CITES data revealed that wild sourced live specimens constitute the largest proportion of this trade. In addition, specimens sourced from ranching operations include various loopholes. There appears to be no facility in any of these three countries that demonstrate a wellestablished captive breeding operation for any species. Thus, it can be confidently assumed that all specimens documented by the CITES trade database that are "officially" declared as exports (as well as those that are non-officially exported) from West Africa are in fact wild animals. This type of trade has had a substantial impact on wild populations of $P$. regius from Benin and Ghana due to gravid female export. In the last 15 years fecundity and mean body size of females has decreased substantially. Average clutch sizes of 15-18 eggs have decreased to 10-12 eggs (at least $\mathrm{n}=5$ females examined each year). Body size has decreased from around $1.5 \mathrm{~m}$ in total length to below $1.4 \mathrm{~m}$. These trends are also coupled with a verified decrease in several Nigerian populations. Wild populations of the Gaboon viper (Bitis gabonica) have also been negatively impacted due to similar and additional threats (Reading et al., 2010).

There is a consensus among reptile traders operating in Togo, Ghana, and Benin that the abundance of $K$. erosa and $K$. homeana has declined over the years (see Luiselli and Diagne, 2013; Luiselli et al., 2013).

The Western Cape Province is home to 153 reptile species and subspecies; approximately $37 \%$ of the reptiles found in South Africa (Turner et al., 2012). Twenty-two species are endemic to the province (Branch et al., 2006). Since 1974, all wild animals in the Cape Province have been classified as protected, and it is illegal to collect, transport, keep in captivity, or export these animals without permission. Nevertheless, some South African reptiles are in high demand in the international pet trade, including the South African girdled lizard genus Cordylus, which has been taxonomically split into several genera (e.g. Smaug, Hemicordylus, Karusosaurus, and Ouroborus [Stanley et al., 2011]). This demand has arisen essentially because these lizards are morphologically diverse; from the small Oelofsen's girdled lizard (Cordylus oelofseni) to the large-scaled girdled lizard (Cordylus macropholis) to the giant girdled lizard Smaug giganteus. This group also includes the armadillo girdled lizard (Ouroborus cataphractus), which, when threatened, characteristically rolls itself in a ball by grabbing ahold of its tail in its mouth to protect its vulnerable belly. All taxa of the previously recognized genus Cordylus have also been listed under CITES since 1981.

Girdled lizards and South African tortoises are regularly sold overseas in the pet trade, and the legal origin is often doubtful. While some South African provinces have allowed exports of wild-caught girdled lizards and of captive-bred tortoises, including angulate and leopard tortoises from the Limpopo Province in South Africa to France (V. Eagan, pers. comm.), CapeNature, the Western Cape provincial conservation agency, has recorded a number of poaching and smuggling activities. From 2001 to 2004, three Czechs, five Slovakian, and nine Japanese citizens were arrested and fined for smuggling tortoises and Ouroborus cataphractus. Following this series of convictions, smuggling ceased for several years. The next and latest case of reptile poaching in the region was in April 2012, when a German and a British citizen were found guilty of the illegal collection of 24 native reptiles, including geckos, snakes, and one tortoise. These cases demonstrate that illegal wildlife trafficking remains a serious and on-going challenge to reptile conservation in South Africa.

Many populations of Madagascar's most threatened reptiles have been extirpated or have declined in abundance and distribution due to the intense pressure from the illegal wildlife trade (e.g., Carpenter et al., 2004). The most heavily traded Madagascan reptiles are endemic tortoises (Astrochelys radiata, A. yniphora, Pyxis arachnoides), chameleons (Furcifer spp., Calumna spp.), and geckos (Phelsuma spp., Uroplatus spp., Paroedura spp.) (Todd, 2011). These reptiles are frequently captured even inside protected areas. The ploughshare tortoise (Astrochelys yniphora), one of Madagascar's trademark species, has been most detrimentally affected by illegal trade, and is now one of the rarest reptile species in the world. The imminent threat to this unique species is the smuggling of adult and juvenile specimens from the wild. The demand by tortoise hobbyists in Thailand, Malaysia, Singapore, Indonesia, the Philippines, China, Japan, Europe, and the United States directly fuels the smuggling activities and has destroyed thirty years of previously successful conservation efforts. In 1997, the Government of Madagascar created a new protected area, the Baly Bay National Park, to protect all remaining wild individuals of the species. However, the illegal collection of ploughshare tortoises from Baly Bay National Park has accelerated over the past 15 years, resulting in very rapid declines in the already depleted populations, and the species is now very close to being extinct in the wild (Pedrono, 2008). In total, $<400$ wild individuals exist, likely fewer than the number of individuals illegally kept outside of Madagascar. Numerous seizures of ploughshare tortoises both in Madagascar and overseas underscore the smuggling pressure on this species. In March 2013, fifty-four ploughshare tortoises were seized in Bangkok Airport just a day after the completion of the global wildlife trade conference, CITES. This seizure represents over $10 \%$ of the entire wild population. Astrochelys yniphora is listed in Appendix I of CITES, which does not permit any commercial trade. All specimens that have been exported from Madagascar have been collected inside the Baly Bay National Park and smuggled out of the country illegally due to their high value on the black market and widespread corruption at multiple levels within the government.

\subsubsection{Asia}

Although national protection and international enforcement measures have improved in this region, complex smuggling networks persist, representing a substantial challenge. Some island nations with range-restricted reptile species (e.g., Sri Lanka) have become the focus of illegal international trade, especially when endemic species are not CITES-listed. Despite national protection and formalized threatened species status assessments, increasing smuggling activities are incentivized by an established consumer base in Europe. South Asian regional dynamics demonstrate how illegal trade activities involves species unregulated by CITES.

With its insular geography and high levels of endemic herpetological diversity, Southeast Asian regional trade dynamics identifies challenges unique to this region. Rare endemic insular species that are protected in their native range, but not regulated under CITES (also see 3.1.4.) have increasingly become the focus of illegal trade, with Europe acting as a primary consumer and supplier to other countries. Illegal trade has become the primary threat to wild populations but national and international policies appear inefficient to deter trade. Complex trade routes and laundering (captive breeding fraud) involving wild-harvested specimens remains the most substantial challenge. These case studies emphasize the severity of the threat caused by international demand for range-restricted CITES and non-CITES species despite national and international regulations. Japan is one of the major worldwide consumers of live reptile species. The country harbours endemic species that have attracted attention in the international pet industry. Despite national protection, many of these species have been reported abroad.

Elevated legal threat status and rarity are the major incentives to illegally collect reptiles that are then laundered through established commercial "breeding facilities." In such circumstances, substantiated cooperation 
between illegal traders and the scientific community has been documented. A summary of East Asian trade patterns provides specific examples (island endemics or range-restricted endemics on the adjacent Asian continent) demonstrating the variability of smuggling activities, which have resulted in a massive and expanding international pet industry.

Although the Indian star tortoise (Geochelone elegans) faces numerous threats, the illegal collection of a substantial number of individuals for the pet trade is the primary threat to this species (Shepherd et al., 2004; Shepherd and Nijman, 2008; Vinke and Vinke, 2010). Enforcement is on-going with this species and many tortoises have been successfully seized at international airports; however, the demand for this species is great and a complex network of smugglers using other modes of trade dispersal remains very active. A high percentage of tortoises die throughout the smuggling process, and most of the confiscated tortoises are small and immature specimens, which may indicate a decline in the population of adults. It is difficult to quantify the effects and magnitude of this trade, but annual wild harvests are estimated between 5000 (Choudhury and Bhupathy, 1993) and 20,000 individuals (Sekhar et al., 2004). Most recently 55,000 specimens were collected at one trade location in India with the principal target markets being Thailand and China (D'Cruze et al., 2015). Collections and possible translocations of this magnitude not only adversely affect recruitment, but may also cause the loss of local adaptations and introduce new pathogens (Alacs et al., 2007).

The tropical island of Sri Lanka is characterized by a high level of endemic and unusually attractive forms of lizard fauna that have entered the European pet market and are exclusively exploited from their natural habitats. Sri Lanka is home to 21 species of agamids, including eight members of the endemic subfamily Lyriocephalinae, (Lyriocephalus, Ceratophora, and Cophotis) (Somaweera and Somaweera, 2009; Amarasinghe et al., 2015). Most of these species have highly restricted distributions and are only found in unique microclimatic pockets (Palihawardana, 1996; Pethiyagoda and Manamendra-Arachchi, 1998; Somaweera et al., 2015). Currently, at the national level, Erdelen's horn lizard (Ceratophora erdeleni), Karunaratne's horn lizard (Ceratophora karu), the leaf-nosed lizard (Ceratophora tennentii) and Knuckles pygmy lizard (Cophotis dumbara) are listed by the IUCN Red List as CR; the rhino-horn lizard (Ceratophora stoddartii), the rough horn lizard (Candoia aspera), and the pygmy lizard (Cophotis ceylanica) are listed as EN, and the hump-nosed lizard (Lyriocephalus scutatus) is listed as VU (Ministry of Environment, 2012).

All Sri Lankan reptiles are protected by the 1937 Fauna and Flora Protection Ordinance (FFP), prohibiting any collection and export except for scientific purposes. In the past enforcement was greatly relaxed, thus some animals in the European pet trade may have originated from legal exports during this relaxed period (e.g., Bartelt et al., 2005). However, smuggling and the illegal trade of $L$. scutatus and Ceratophora spp. has continued in recent times, and several countries now offer these species occasionally, including Germany (Altherr, 2014), Japan (Hettiarachchi and Daniel, 2011; Karunarathna and Amarasinghe, 2013), and Taiwan (Shiau et al., 2006). Local media publicized several incidents of Sri Lankan reptiles and other species being sold in Germany (Hettiarachchi, 2010; Hettige, 2011), and incidents of Europeans arrested in Sri Lanka while having reptiles in their possession (Rodrigo, 2012). In 2012, German pet traders urged the Export Development Board of Sri Lanka to resume reptile and amphibian exports to meet the demand in the EU (Anonymous, 2010a; Fernando, 2010). However, this idea was severely opposed by environmental activists (Anonymous, 2010b; Paranamanna, 2011) and halted.

Since 2013 an alarming abundance of adult Sri Lankan agamids has been documented in European online advertisements; including most members of the subfamily Lyriocephalinae as well as the black-cheek lizard (Calotes nigrilabris) and the Sri Lankan kangaroo lizard (Otocryptis wiegmanni). This indicates that there have been several recent smuggling events. These smugglers are based primarily in Russia, Italy, and France, and advertised these animals at very high prices: $C$. stoddartii
( $€ 1000 /$ pair), C. ceylanica ( $€ 2200 /$ pair) and L. scuttatus (up to $€ 1600 /$ pair).

A Bornean endemic, the earless monitor lizard (Lanthanotus borneensis), has become a species in great demand, particularly popular in the European pet market (Altherr, 2014; Nijman and Stoner, 2014). Despite being protected in its three potential range states of Indonesia (Kalimantan), Malaysia (Sarawak), and Brunei Darussalam, the lack of regulations protecting the species in consumer states enables international trade.

Over a 17-month period beginning in May 2014, Stoner and Nijman (2015) documented the online sale of nearly 100 earless monitor lizards from 35 different traders in 11 countries. The findings illustrated the global nature of this trade, though not so prevalent as that in Europe (Nijman and Stoner, 2014). Trade is occurring both in and out of Europe and, consistent with trade dynamics in other high-value reptiles, Germany is among the most pervasive of consumer states. Traders have offered earless monitor lizards for sale on specialist websites and specifically mention the reptile trade fair "Terraristika" in Hamm, Germany, held quarterly each year, as a place where individuals can be obtained after they have been purchased online. The species has also been documented for sale online in the Czech Republic, France, the UK (originating from Germany), and the Ukraine. This concentration of trade on mainland Europe is further compounded by traders in the EU directly supplying the USA market, making Europe an important consumer as well as a significant supplier. This continuing supply may account for an observed fall in price. At its highest point, the species was offered for sale for as much as US\$15,500 (USA) and €9600 (Germany) but more recently prices have dropped to $€ 3000 /$ pair.

When buyers in the United States purchase this species from European traders it circumvents the US Lacey Act, which would prevent them from legally obtaining individuals directly from range states where the species is protected. No legislation comparable to the US Lacey Act exists in the EU, and since the species is not listed in the Appendices of CITES, or the Annexes of the EU itself, there are no mechanisms to prevent the trade within the EU, regardless of the illegal sourcing from the range states (Altherr, 2014).

The estimated count of the earless monitor lizard in trade is suspected to be conservative and only reports on the number observed for sale online. More crucial is the paucity of data on the species occurrence; the impact of trade and instances of removal from the wild cannot be quantified. The authenticity of captive breeding claims that are circulating for this species on specialist online forums are still under question; however, individuals are certainly being taken from their natural habitat. In October 2015, the first seizure and arrest was made at the International Airport in Indonesia's capital Jakarta, when a German national was found in possession of eight earless monitor lizards. Each specimen was purchased from a trader in Kalimantan, Indonesian Borneo, allegedly for around $€ 3$ (Anonymous, 2015), resulting in a substantial mark-up for those operating at the consumer end of the trade chain. More recently in March 2016, 17 specimens were seized from a German national at Supadio airport in Pontianak, capital of West Kalimantan (Anonymous, 2016).

Siebenrockiella leytensis is the only endemic semi-aquatic turtle in the Philippines (Diesmos et al., 2004). Taylor described the species in 1920 based on two specimens (Taylor, 1920) and over the next 30 years few additional individuals were reported (Buskirk, 1989). Wild populations in Palawan were only rediscovered in late 2001 (Diesmos et al., 2004). Publication of the rediscovery of wild populations of this rare and endemic turtle in Palawan (Diesmos et al., 2008, 2012) triggered an immediate interest from turtle hobbyist, who obtained specimens to the detriment of this species just a few months later (Schoppe and Cervancia, 2009; Schoppe et al., 2010). Although the Philippine Republic Act Number 9147 (Wildlife Resources Conservation and Protection Act) prohibits the collection of Philippine wildlife without proper permits, it did not prevent wildlife collectors and traders from illegally procuring and trading S. leytensis on local and international wildlife markets. Illicit 
trade of S. leytensis in Metro Manila was first documented in 2004, when 300 specimens were detected in two private facilities in Quezon City and Pasay City. Specimens fetched prices of $€ 2000$ in the European pet market (Gavino and Schoppe, 2004; Diesmos et al., 2008). Illicit trafficking has been consistently documented within the period 2004-2010, including a seizure of $>600$ individuals in Taytay, Palawan (Diesmos et al., 2008,2012 ) and a record seizure of $>4000$ specimens in June 2015 in a warehouse in southern Palawan (Sy, 2015; TRAFFIC, 2015). The international pet trade is the greatest threat to this species (Diesmos et al., 2008, 2012; Schoppe and Shepherd, 2013).

The crocodile lizard (Shinisaurus crocodilurus), formerly known only from southern China, and since 2003 also from a few sites in northern Vietnam, was recently included in the IUCN Red List (Nguyen et al. 2014). The species is currently on the brink of extinction due to severe habitat loss in its restricted distribution, together with massive over-exploitation of the already heavily diminished and isolated wild populations. Its prominent color patterns and primeval appearance have made the species more popular among hobbyists especially from Europe (van Schingen et al., 2015). Following the species' inclusion in CITES Appendix II in 1990, the international trade in S. crocodilurus switched almost entirely to allegedly captive bred specimens, although there is clear evidence for the illegal origin of numerous specimens (van Schingen et al., 2015). Smuggling of wild-caught individuals to Japan and via Cambodia to Thailand, the false declaration of specimens and dubious trade via Kazakhstan and Lebanon, as well as the covert sale at the reptile fair in Hamm, Germany, have been well documented (e.g., Kanari and Auliya, 2011; van Schingen et al., 2015; pers. obs.). Recent population estimates of the species revealed 950 individuals in the Chinese populations (Huang et al., 2008) and only 100 individuals remaining in northern Vietnam (van Schingen et al., 2014). Recently, interviews with villagers in Vietnam confirmed that the collection of these lizards for trade has been more frequent than originally thought, which already has resulted in extirpation at some sites (van Schingen et al., in press).

In 2010, Grismer et al. described C. psychedelica, characterized by remarkably bright colors, as endemic to the small island of Hon Khoai in southern Vietnam. The first advertisements of this new species appeared on European Internet platforms in 2013, even though export of wildlife from Hon Khoai is prohibited. At the reptile fair in Hamm (Germany), in June 2014, at least nine pairs of C. psychedelica were offered by online unconnected adverts (Altherr, 2014). In 2015, a German dealer offered specimens to be exported to the USA, and in the same year the first adverts from the USA appeared. From 2013 to 2015, a total of 21 offers of $C$. psychedelica were noted. Ten of the internet offers (between 2 and 16 specimens) derived from Russia, three from Germany, three from Spain, one (10 specimens) from Czech Republic, and one (4 specimens) from the USA. Prices, if specified, varied between $€ 1500-3500 /$ pair; juveniles declared as captive bred offspring were offered for $€ 500$ by one trader from Russia. Range-restricted populations are especially prone to extinction, thus poaching is assumed to have tremendous impacts on the species' survival. Due to the small area of the island and the overall easy accessibility there are few possibilities for population recovery in C. psychedelica. Furthermore, the species' assumed low reproductive rate limits its ability to recover from this level of harvesting.

Japan is home to 13 Testudines spp., 38 Lacertidae spp., and 41 snake species, some of which are introduced species (Herpetological Society of Japan, 2013). The country is also a major importer of live reptiles (Auliya, 2003). In 2013, Japan imported $>317.000$ specimens of reptiles from 52 countries (Japan Customs, 2014). Due to the archipelago's geographical position between Asia and North America, the domestic market reveals an enormous diversity of species offered in both pet shops and the online market, with more than half of the world's tortoise species being sold in Japan (Kanari, 2010). The largest supplier of live reptiles to Japan is the Asian continent. Since 1980, Japan has been a party to CITES, and the objectives of CITES are implemented through the Act on Conservation of Endangered Species of Wild Fauna and
Flora of 1992, which regulates domestic trade in wild species. Japan also protects national reptile species for cultural reasons. The Act on Protection of Cultural Properties of 1950 was enacted for protection of culturally important species as Natural Monuments (Kanari and Xu, 2012). Despite policies in place, illegal trade in reptile species continues; in fact, reptiles are the most prominent species involved in smuggling activities, particularly at the Japanese border (Kanari, 2010). At the CITES CoP16 in 2013, Japan submitted the first ever proposal for a native species, the Ryukyu black-breasted leaf turtle (Geoemyda japonica), which is endemic to the central Ryukyu Islands. The proposal was due to the species' abundance in the international trade and illegal trade activities demonstrating the likelihood for its decline, (Yasukawa and Ota, 2008). For example in the EU specimens are sold for EUR1000-1900 (Altherr, 2014; https://cites.org/sites/default/files/eng/cop/16/prop/ECoP16-Prop-34.pdf - accessed 1 April 2016). Although the species was already fully protected by Japan's National Act on Protection of Cultural Properties, the listing in CITES Appendix II strengthened trade monitoring at the international enforcement level.

The illegal trade of turtles in China has been relatively well documented (Cheung and Dudgeon, 2006; Gong et al., 2009; Zhou and Jiang, 2008). Shi et al. (2007, 2008) discuss the laundering of wildcaught turtles by a giant largely unregulated turtle-farming industry that trades illegally collected turtles as captive-produced fare. Accordingly, these facilities represent a major threat to wild turtles. Further, Zhou et al. (2008) document how news of the high prices offered for rare turtles in the pet trade has reached even remote mountain villages. The value placed on $\mathrm{CR}$ species by the pet trade represents the major threat for some species by presenting incentive to collect every individual. The illegal pet trade in wild caught turtles and general overharvesting preceded scientific study, resulting in poor or absent locality information for some species. Pan's box turtle (Cuora pani), for which the actual locality was not known for many years (Parham and Li, 1999), McCord's box turtle (Cuora mccordi), Yunnan box turtle (Cuora yunnanensis), Zhou's box turtle (Cuora zhoui) (reviewed by Parham et al., 2001, [see Table 1], Parham et al., 2004 [see Fig. 1c], and the yellow-margined box turtle (Cuora flavomarginata) (Fong et al., 2002) exemplify this. Linkages to the European market have been outlined in the CITES proposal listing the genus Cuora in Appendix II (see https://www.cites.org/eng/cop/11/prop/36.pdf - accessed 23 February 2016). The illegal pet trade in turtles is an exceptional case that includes the scientific community. Dalton (2003) outlines how a Chinese smuggler supplied taxonomists with exotic turtles, using a New York veterinarian as an intermediary. Resultant confusion included the establishment of pointless captive breeding programs for human-produced hybrids, wasted field efforts, and a general drain on conservation energies (Parham et al., 2001; Stuart and Parham, 2007).

\subsubsection{Oceania}

Despite national protection of all native reptiles in some nations (New Zealand, Australia), the unique morphology, behaviour, and rarity of the region's endemic reptiles drives a high international market value for its reptile fauna. Documented extirpations of native reptiles appear to be related to an Oceania-specific consumer market in Germany. Despite strong enforcement, the existence of legal loopholes and captive-breeding fraud are substantiated by the preponderance of Oceania endemics commercially available abroad. Regional patterns indicate that even strong enforcement may not sufficiently deter smugglers of wild-caught animals - if the international market value for rare, endangered, and protected species is high.

New Zealand has a unique and distinctive fauna due to its long history of geographic isolation (Daugherty et al., 1993). Its reptiles are highly sought-after by animal collectors, particularly the tuatara (Sphenodon punctatus), an ancient reptile that is the last remaining member of the order Rhynchocephalia, and the Naultinus geckos (nine species collectively referred to as 'green geckos'). Naultinus spp. are of special interest because they are, in contrast to most of the world's gecko species, diurnal and brightly colored. Both the green geckos and the 
tuatara are highly desired because of: (1) a lack of availability (all native New Zealand reptiles are protected by the Wildlife Act, which prohibits their sale and export); (2) unusual life-history traits, including viviparity, slow growth, low reproductive rates (Cree, 1994), and extreme longevity (tuatara and New Zealand geckos are known to have reached ages of 91 and 53 years, respectively); (3) uniqueness (99\% of New Zealand's terrestrial reptiles are endemic); and (4) rarity: most of the native New Zealand lizard fauna is threatened or at risk of extinction ( $83 \%$, or 82 out of 99 terrestrial species, including some undescribed taxa; Hitchmough et al., 2013). Even relatively common New Zealand gecko species, such as Woodworthia spp. and Mokopirirakau spp., are also targeted by wildlife collectors, and sold on the European pet market for high prices (e.g., €2200/pair of W. cf. brunnea, $€ 5300 /$ pair of $M$. granulatus and $€ 3700 /$ pair of Naultinus elegans).

Many reptile populations in New Zealand are already small, fragmented, and threatened by predation and habitat loss. The illegal collection of individuals from a wild population is yet another threat that compromises their long-term viability and may extirpate some populations. For example, a population of jewelled geckos (Naultinus gemmeus) on the Otago Peninsula declined from about 70 individuals in 1994 to just two individuals in 2008: a decline of $>95 \%$, in part caused by illegal collection (Lettink, 2010). Anecdotal information indicated that a German national was sending persons to collect geckos from a certain site until they were almost gone. Even the impact of a single poaching event can be severe, as illustrated by a recent case in which 16 jewelled geckos (including 11 females, nine of which were gravid) were collected from another site that contained ca. 70 individuals (Knox, 2010). If these animals had not been returned to the wild, this population would have lost almost half of its breeding females and a quarter of its residents (Lettink, 2010). Within a year of the release of these animals, in 2010, collectors again targeted the site, and an unknown number of animals were taken and exported from New Zealand. Some animals were subsequently found advertised for sale on a German website (geckos were identified from their unique dorsal markings, which had previously been recorded in a photo library). Since 2001, eight people, including six German nationals, have been convicted for illegal collection and possession of New Zealand reptiles. This is thought to represent only a fraction of those involved, with significant numbers of reptiles being illegally exported to satisfy the growing market.

Being one of the 17 mega-diversity countries, Australia is known for its herpetological diversity, with at least 917 recognized reptile species and approximately 93\% endemism (Mittermeier and Mittermeier, 2004; Chapman, 2009). Export of wildlife is strictly regulated under the nation's key environmental law, the Environment Protection and Biodiversity Conservation Act 1999, which was enacted in July 2000. Commercial export of native animals may only be permitted for dead specimens from approved sources. No export of live reptiles is permitted (Department of the Environment, 2015). However, endemism, morphological peculiarities (e.g., Tiliqua rugosa, Moloch horridus), and the intense colors and patterns of many Australian species are highly attractive to overseas collectors. Indeed, several cases of illegal trafficking have been recorded in recent years, including arrests of the persons involved.

In February 2015, two Russian and two Czech citizens were arrested after trying to smuggle 157 reptiles and amphibians, including skinks, geckos, and pygmy pythons (Antaresia spp.) (ACBPS, 2015). The court case ended with a 12-month prison sentence (Menagh, 2015). Pygmy pythons may fetch up to €1200 Euro/pair in the EU market; online offers are made by traders from several European countries.

In October 2015, the Australian Border Force at the Perth International Mail Gateway confiscated fifteen native Australian lizards concealed in parcels bound for Slovakia, including ten spiny-tailed geckos (Strophurus ciliaris), three bearded dragons (Pogona sp.), and two thorny devils (Moloch horridus) (ABF, 2015). A pair of spiny-tailed geckos, offered by a German trader, fetches approximately €1000 Euros; black market prices for thorny devils are estimated at over $€ 10,000$.

From August to September 2007, 40 reptile retail shops were visited in the regions of Kanto, Kansai, and Chubu, Japan. Almost 50 reptile taxa originating from Australia were recorded, mainly consisting of freshwater turtles, geckos, and monitor lizards, including one adult Perentie monitor (Varanus giganteus) (Kanari and Auliya, 2011).

\subsubsection{Central and South America}

Conditions are optimal for illegal trade activities in this region due to the lack of enforcement and domestic infrastructure, and widespread poverty. Several endemic species and populations have been detrimentally impacted and partially extirpated by the illegal international pet trade. The occurrence of a global hot spot of reptile diversity and endemism in the region is associated with international demand for many of its unique reptiles. Illegal trade in iconic, highly endangered species (e.g., Galápagos iguanas) elaborate trade routes to countries like Switzerland and Germany via western Africa. These case studies demonstrate the broad extent of illegal trade networks that are created, when smugglers can reliably exploit conditions in which national regulatory measures fail as a result of limited resources and weak enforcement.

The reptile fauna of Central America is comprised of $>550$ species (Köhler, 2008), many of which are targeted for the pet trade. Several of these species have narrow ranges and are threatened with habitat destruction and harvesting for local consumption (e.g., Pasachnik, 2013). When the threat of international trade is added, extirpations can be expected. The most sought-after reptile species from Central America are the spiny-tailed iguanas (Ctenosaura spp.) (Cotí and Ariano-Sánchez, 2008), Hog Island pink boas (Boa imperator; formerly recognized as a subspecies of Boa constrictor) (Reed et al., 2007), several turtles (specifically Trachemys and Kinosternon spp.) (Schlaepfer et al., 2005), the Guatemalan beaded lizard (Heloderma charlesbogerti) (Ariano-Sánchez and Salazar, 2015), the arboreal alligator lizards (Abronia spp.) (Ariano-Sánchez and Melendez, 2009; Ariano-Sánchez and Torres-Almazán, 2010), and the arboreal pit vipers (Bothriechis spp.) (CONAP, 2011). The situation in Central America is optimal for illegal trade: there is a high demand for many species, a lack of enforcement, bribery is well accepted, and immense poverty causes people to take risks for little profit. In addition, border control and government communication between countries is lacking, and smuggling routes are already well established because of the drug trade. Guatemala has been identified as an important route into El Salvador, from which animals are sent to Europe along with legal shipments of green iguanas (TRAFFIC reports over 225,000 green iguanas imported into the EU from Central America from 2005 to 2006). Highly threatened species such as $A$. campbelli, Ctenosaura palearis, Bothriechis aurifer, and Heloderma charlesbogerti have been detected along this route. In Europe, the entrance ports are usually the Czech Republic and Spain. In 2009, five $H$. charlesbogerti that had followed this route were confiscated from a private zoo in Denmark. The remaining population of $H$. charlesbogerti is believed to be $<500$ individuals. From 1993 to 2003 at least $10 \%$ of the population was taken from the wild to supply the illegal pet trade in the USA and Europe (Ariano-Sánchez and Salazar, 2015). The use of international courier services has also been identified as a way to traffic animals to Europe. In 2009, three Abronia vasconcelosii were found inside a videotape and were intercepted at Gatwick airport in the United Kingdom. This parcel was in route from Guatemala to the Czech Republic. Guatemalan authorities have identified one Mexican (partially residing in Spain) and one Czech national as playing major roles in this trade route.

The impact that trade can have on natural populations is exemplified below. LEMIS, the Law Enforcement Management Information System of the U.S. Fish and Wildlife Service, reported 240 wild-caught Ctenosaura palearis, endemic to the Motagua Valley, Guatemala, taken for commercial purposes in 2008, allegedly unknown to Guatemalan 
authorities. Locals advised that 50-60 individuals were collected for export each month and that they have noticed a dramatic decline of $C$. palearis in the past 20 years (Ariano-Sánchez and Pasachnik, 2013). Researchers visiting these areas reported the extirpation of several of these populations following extensive surveys (Cotí and Ariano-Sánchez, 2008). In addition, the presumed extinct Guatemalan endemic, $A$. campbelli, was rediscovered in 2009 (Ariano-Sánchez and TorresAlmazán, 2010). Interviews with locals shortly after the rediscovery showed that 48 individuals were being kept in captivity waiting to be collected by a smuggler (paying US $\$ 5$ each) following a previous agreement for export. Had the timing of the interviews been only slightly later, the status of this species may be very different.

In Honduras, an insular population of Boa imperator exhibits dwarfism as well as a unique pink coloration that has been prized in the pet trade (Reed et al., 2007). Between the 1970s and 1980s, thousands of snakes were harvested from the wild (Porras, 1999; Reed et al., 2007), and, within a decade, not a single adult boa could be found on these islands during a rapid survey (Wilson and Cruz Diaz, 1993). In 1993, the Honduras Coral Reef Foundation was created, and the area was legally declared a Marine National Monument in 2003. Through these actions poaching has decreased dramatically; however, illegal removal is still being reported and these animals are being confiscated.

Mexico ranks second in the world (after Australia) in regards to reptile species diversity. Uetz and Hošek (2015) report 943 species for Mexico with almost $60 \%$ endemic to the country (see Flores-Villela and García-Vázquez, 2014). The country has very restrictive laws regulating capture and export of wild-caught reptiles. However, due to limited resources and capacity for enforcement, the illegal collection of reptiles is pervasive, even inside natural protected areas (Lovich et al., 2009). Many Mexican endemic species are highly sought-after in the international pet trade, including the Isla Todos Santos mountain kingsnake (Lampropeltis herrerae) and the Santa Catalina Island rattlesnake (Crotalus catalinensis). Both species are (1) classified as CR by IUCN Red List, (2) have limited ranges $\left(<100 \mathrm{~km}^{2}\right.$ for $L$. herrerae and $40 \mathrm{~km}^{2}$ C. catalinensis), and hence are highly prone to over-collection for the pet trade (Grismer, 2002; Avila Villegas et al., 2007; Hollingsworth and Frost, 2007), and (3) categorized in Mexico as threatened species "A" (threatened) (SEMARNAT, 2010). In addition, lizards such as the endemic San Lucan banded rock lizard (Petrosaurus thalassinus) are being illegally collected by the thousands for the international pet trade (Grismer, 2002), and other Mexican endemics, including the four-toed worm lizards (Bipes canaliculatus, €2000), Creaser's mud turtle (Kinosternon creaseri), Herrara's mud turtle (Kinosternon herrerai), and the Jalisco mud turtle (Kinosternon chimalhuaca), are for sale in Europe.

Mexico is home to 18 species of arboreal alligator lizards, (Abronia spp.), of which 17 are endemic. According to the Official Mexican Norm 059 (SEMARNAT, 2010), five Abronia species are listed as "P" (in danger of extinction), seven as " $\mathrm{A}$ " (threatened) and two as "PR" (subject to special protection), which makes any collection without a permit illegal, and those classified as "A" can only be collected for conservation purposes. In addition, six of these Abronia species are classified as EN, and two as VU by the IUCN Red List. The only legally exported species in this genus is Abronia graminea (listed in EU Annex D) due to the presence of a small Mexican captive breeding program that has been allowed to legally export a few individuals. No legal export has been permitted for any other species of Abronia (Conabio 2013 in litt. to Altherr, 2013) yet A. graminea is the most commonly traded species of its genus, and A. deppii, A. lythrochila, A. martindelcampoi, A. mixteca, and $A$. taeniata can be seen regularly in the pet trade (Altherr, 2014). Abronia martindelcampoi can achieve a price of $€ 1200$ and $A$. mixteca $€ 4000 /$ pair. European traders offering Abronia spp. are most often from Spain, which is a known gateway for Latin American species to Europe.

Spiny-tailed iguanas (Ctenosaura spp.) are also targeted by smugglers, of which 11 species are native and nine are endemic to Mexico.
None of the Mexican Ctenosaura spp. are protected by CITES, but all of them are covered by Mexican law, prohibiting exports without permits. Only two species (Ctenosaura pectinata and Ctenosaura defensor) have been exported legally since 2000, but none to the EU (SEMARNAT, 2015). Nevertheless, at least nine Mexican Ctenosaura spp. are available in the European pet market, with prices between $€ 150$ for Ctenosaura similis and $€ 1340$ for Ctenosaura conspicuosa.

Of $>40$ reptile species native to the Galápagos Islands (Ecuador), six terrestrial species are threatened (IUCN, 2015). The islands represent an attractive source of specimens for private collections and have been receiving increasing attention from illegal traffickers. Four smuggling cases occurred between 2010 and 2015, with captured smugglers from e.g., Germany being prosecuted. These cases involved the illegal export of marine iguanas (Amblyrhynchus cristatus), terrestrial iguanas (Conolophus subcristatus), and a giant tortoise (Chelonoidis sp.).

Regarding the Conolophus subcristatus event, molecular tools were used to unambiguously assign and return the four iguanas to the proper population (Gentile et al., 2013). In this case, molecular tools were also used to produce a forensic report that contributed to sentencing the illegal smuggler to four years in prison, as he was found guilty under Articles of the Ecuadorian Criminal Code. In 2014, the Galápagos National Park started a program aimed at detecting and uncovering the network of illegal traffickers operating in Galápagos.

The UNEP-WCMC CITES trade database (2015) confirms that Ecuador has never declared export of live specimens of $C$. subcristatus or $A$. cristatus for commercial trade. Nevertheless, two live land iguanas and three live marine iguanas were officially exported from Mali to Switzerland in 2011 and 2012, respectively, labelled as "captive-bred" and for private purposes. In 2014, the Swiss CITES management authority issued export permits to Uganda for these animals, which for all practical purposes laundered these animals into the pet trade, and opened the door for additional smuggling events, claiming captive breeding. As was predicted, in September 2015 a Mexican citizen was arrested in Ecuador for attempting to smuggle an additional 11 juvenile Galapagos Marine iguanas to Uganda, underlining the role of Uganda as a transit point or laundering location in this on-going operation.

\section{Discussion}

This review provides a new perspective on the global reptile pet trade as it brings together key expert testimony from around the world that cannot be found elsewhere in the literature. Additional regions could not be included directly in this review (e.g., the western and southern Mediterranean area, the Canary Islands, the United States, New Caledonia, and eastern Africa); however, it is evident that they are affected by legal and illegal reptile pet trade as has been reported previously (e.g., Klemens and Moll, 1995; Bauer and Sadlier, 2000; Litzgus and Mousseau, 2004; Bertolero et al., 2011; Bauer et al., 2012). For many cases highlighted herein this is their first exposure to widespread awareness, and consequently a call to action for scientific and management authorities worldwide.

More than $90 \%$ of the world's reptiles are not regulated by CITES and the EWTR. This implies that non-CITES species, nationally threatened or newly discovered taxa (that commonly represent endemic taxa of charismatic species groups that have triggered international demand) are not protected from over-exploitation unless. However, as the case studies highlight, many species controlled under current policies are also illegally traded to supply the international reptile pet market (e.g., Alacs and Georges, 2008; Shepherd and Nijman, 2008; Nijman et al., 2012; Wyatt, 2013; D'Cruze et al., 2015). The current law and enforcement afforded to this cause is weak, partially caused by limited capacity (Sellar, 2014), in comparison to similar illegal trade, such as in drugs, arms, and human beings. In many regions presented within the case studies, the lack of enforcement capacity is mainly owed to understaffed authorities (e.g., Baard and de Villiers, 2000). These issues combined result in persistent illegal trade activities, and the continued over- 
exploitation of many species. Species examples covered in the case studies provide strong evidence that endemic species (e.g., species landlocked in mountain regions or oceanic islands) are those most targeted, and that on-going offtakes (attracted by international demand) can lead to the extirpation of species. However, localized over-exploitation of wide-ranging species can also lead to increased fragmentation and a reduction in gene flow, as exemplified by the intense illegal collecting of the Egyptian tortoise (Testudo kleinmanni) (Perälä, 2003) and several insular populations of the green tree python (Morelia viridis) (Lyons and Natusch, 2011).

A significant number of reptile populations have already been severely decimated for the pet trade (e.g., Klemens and Moll, 1995; Ariano-Sánchez and Torres-Almazán, 2010; Horne et al., 2011; Flecks et al., 2012), and evidence is provided within numerous CITES listings of species for which the pet trade poses a major threat. Chelodina mccordi (see above), the Burmese star tortoise (Geochelone platynota), Testudo kleinmanni (see above), numerous Asian box turtle species (Cuora spp.), the Mangshan pit viper (Protobothrops mangshanensis, see Gong et al., 2013) and many others (see https://www.cites.org/ eng/com/ac/index.php) exemplify this.

The case studies clearly demonstrate that rare, geographically isolated, or protected reptile species trigger smuggling activities, as these species procure high-prices on the black market due to their paucity in the trade (Brook and Sodhi, 2006; Hall et al., 2008; Lyons and Natusch, 2013). Since scientific descriptions of new species are used as signposts for smugglers, an increasing number of herpetologists refrain from publishing detailed localities and do not support 'uplisting' to a more restrictive CITES Appendix as a preventative measure to avoid making these species more valuable (Rivalan et al., 2007). This results in a lack of proper listing and potentially management efforts, but is a last resort given the lack of trade enforcement currently present.

Although some entities would prefer a complete ban on all reptile trading this is an unlikely and controversial approach. Thus, in the event that national harvests of selected species (that represent a wider distribution, and display favorable life history traits) are allowed it is imperative that this is done in a sustainable manner (Leader-Williams, 2002). There are numerous examples of species (e.g., micro-endemics, those with prolonged sexual maturity and low reproductive output) that will be negatively affected if their trade is permitted. In addition, species yet to be assessed by the IUCN Red List occur in trade. Decision makers are therefore advised to network with experts e.g., of the IUCN Global Species Programme and their specialist groups to gain trade-relevant information to understand its impact on the relevant species.

One of the major issues and challenges is the fact that most species involved in legal trade are confronted by numerous uncertainties not only related to the species' biological and ecological traits. This, in particular, relates to species listed in CITES Appendix II, which may only be exported if sustainably harvested, so that the viability of their populations, and thus their role in the ecosystem, can be maintained (Article IV - https://www.cites.org/eng/disc/text.php\#IV - accessed, 21 Oct. 2015). However, in practice, the need for a Non-Detriment Finding is commonly not met due to the lack of biological and collection data (Smith et al., 2011), but also due to economic pressure or lack of political will (see Lyons and Natusch, 2011). A striking example of CITES Appendix II species, that are traded without any NDFs, are monitor lizards endemic to Indonesia. Among nearly 30 species, five are nationally protected and six have been allocated an annual export quota. In more than ten species, adaptive management measures are not in place, and these species in particular are endemic to small islands e.g., Varanus obor, V. kordensis, V. macraei or V. boehmei; all these species are involved in the international pet trade (http://trade.cites.org; Uetz and Hošek, 2015).

There are many challenges to the effective implementation of these provisions (Nash, 1993; Gomar and Stringer, 2011). A major prerequisite to achieve this condition is the monitoring of the populations in question (Henle et al., 2013) and the provisioning of scientific knowledge to overcome uncertainties in this regard. However, in reality even trade that is well established among many reptile species lacks fundamental knowledge of the species' population dynamics over time. It is opportune to develop methods for a precautionary approach ("precaution is one of the guiding principles of environmental laws in the EU"; Kriebel et al., 2001) to preserve biodiversity rather than to support national economies or at a minimum to balance the protection of biodiversity and economic growth. Two range-restricted species, $V$. boehmei (CITES Appendix II) and the non-CITES listed Philippine pit viper (Trimeresurus mcgregori), exemplify this issue. Both species are classified as data deficient (DD) in the IUCN Red List, and are in fact heavily impacted by the international pet trade (Bennett and Sweet, 2010; Koch et al., 2013; Sy et al., 2009).

EU authorities should be aware of frequency in which some traders fraudulently declare their animals to have been bred in captivity. This can in reality represent individuals taken directly from the wild or the offspring of a gravid female giving birth or laying eggs soon after a smuggling event. Further, even for the truly captive bred individuals that are nationally protected in their native range and for which legal exports have never been permitted, the question on the legality of their breeding stock remains. The EU authorities should take more care to verify the validity of captive breeding claims by cross-checking with authorities in the native range countries before permitting imports or issuing exports. Too often a lack of this thorough investigation into the original export paperwork from the country of origin has resulted in the laundering wild reptiles as captive-bred, farmed, and has been well documented (Kabigumila, 1998; Shi et al., 2004; Vinke and Vinke, 2010; Pedrono, 2011; Lyons and Natusch, 2011; Sy, 2014).

Europe, as one of the major consuming regions worldwide in the live reptile trade, needs to take responsibility for the conservation of species outside its range (Gruttke, 2004). The approach to determine national responsibility to conserve and protect species has been elaborated more recently, developing a National Responsibility Tool that "uses a GIS-based approach to determine the international importance of a species distribution area in a focal area" (Schmeller et al., 2014). This approach has already been explored for regions outside Europe and should be established globally to monitor the conservation status of reptiles involved in the pet trade.

Nationally protected species not regulated by CITES cannot be adequately protected from exploitation on the international market once illegally removed out of their native range, leaving the responsibility to combat this form of wildlife crime solely with the countries of origin (Vinke and Vinke, 2015). The EU, with its wealthy clients and lack of internal barriers, is considered a main destination for smuggled wildlife, including reptiles (Auliya, 2003; Engler and Parry-Jones, 2007; http:// eur-lex.europa.eu/legal-content/EN/TXT/PDF/?uri=CELEX:

52016SC0038\&from=EN - accessed, 22 March 2016), but has no legal basis to seize specimens, which were illegally obtained or to penalize smugglers discovered in their range states. In contrary, such nationally protected species are covered in the US by the Lacey Act, that e.g., "prohibits the import, export, acquisition, receipt, sale or purchase in interstate or foreign commerce of any fish or wildlife taken, possessed, transported, or sold in violation of any wildlife law or regulation of any state, or in violation of any foreign law" (Hoover, 1998). The US Lacey Act therefore enables US authorities to seize such animals and to place fines on related smugglers. In November 2015, a joint letter from 156 scientists, field biologists, and conservationists from 45 countries, called on the EU Commission to pass equivalent legislation. The decision is currently pending.

In July 2015, the Members of the EU joined a Resolution of the United Nations on confronting illicit trafficking in wildlife, to develop an EU Action Plan against Wildlife Trafficking. This EU Action Plan was launched February 2016 and aims to tackle wildlife trafficking (http://eur-lex. europa.eu/legal-content/EN/TXT/PDF/?uri=CELEX:

52016SC0038\&from =EN - accessed, 22 March 2016). While the EU Action Plan does not provide for new legislation so far, a study of the EU 
Parliament on wildlife crime (published only a few days later), recommends that the EU "should consider measures to curtail activities involving wildlife species protected by laws of their countries of origin (only); this may include new legislation, making import, sale, purchase and re-export of specimens, which have been captured, traded or exported in violation of laws in the country of origin a criminal act within the EU" (http:// www.europarl.europa.eu/RegData/etudes/STUD/2016/570008/IPOL_ STU(2016)570,008_EN.pdf - accessed, 28 March 2016). It is noted that the American "US Lacey Act" provides "a simple and realisable model for such an approach".

Although not discussed in depth here, the mortality rate of reptiles from the point of harvest to the final destination is an additional concern. Studies indicate pre-export mortalities for reptiles of up to $13.3 \%$ in Togo (Harris, 2002) and up to 50\% for chameleons in Madagascar (Brady and Griffiths, 1999). During international transport a mortality rate of 3.14-4\% on average was recorded, with significantly higher losses in skinks (up to 14\%) and chameleons (7\%) (Steinmetz et al., 1998; Schütz, 2003). However, the impacts of reptile trade on biodiversity are not limited to the targeted reptile population but also contribute to the destruction of many habitats and thus a plethora of other species (Goode et al., 2004a). For example, trees are cut to collect arboreal reptiles (e.g., Philippine frugivorous monitor lizards, the Polillo false gecko [Pseudogekko smaragdinus], and L. williamsi, which inhabit palm-like Pandanus trees; Flecks et al., 2012), rock crevices are broken open, and rocks and logs are overturn on a regular basis (Hollingsworth and Frost, 2007; Goode et al., 1998, 2004b). Additionally, many of the species targeted are ecosystem engineers or keystone species in their respective ecosystems. For example, Rock Iguanas (Cyclura) help maintain and perpetuate native plant communities, such as dry forests, which are among the most endangered in the world. Thus depleting an area of such species may result in ecosystem degradation. It has been postulated that harvesting of species that inhabit very specific isolated ecosystems, such as on islands, accelerates the extinction even more than habitat destruction (e.g., Machado et al., 1985; Asian Turtle Trade Working Group, 2000).

\section{Conclusions and recommendations}

Herein we have showcased a plethora of cases in which legislation and enforcement are insufficient, and species and populations are being depleted because of wildlife trafficking. To address this, a National Legislation Project (NLP) has been established by CITES to analyse CITES relevant legislation in the member States (see https://cites.org/eng/ legislation - accessed 2 May 2016). The data presented herein may be used by CITES in the aforementioned project but should also be used as a call to action for many countries, particularly those within the EU to step forward and control these activities such that global reptile diversity may be conserved. Managers and those involved in the NLP should pay specific attention to the following:

1. The legal and illegal trade in various reptile species, largely endemic to megadiversity countries and biodiversity hotspots, should be considered detrimental to their survival.

2. Numerous nationally protected species, often listed as threatened by the IUCN Red List because of illegal and unregulated trade activities, are not listed in the appendices of CITES.

3. Many species yet to be assessed by the IUCN Red List are heavily traded and also under the appendices of CITES.

4. No regulations are in place to monitor the unsustainable trade of range-restricted rare species that lack protection and appropriate listings.

5. Numerous species listed in CITES Appendix II, that reflect island endemics and/or are threatened, can be traded legally, and non-detriment findings have not been elucidated by the relevant scientific authorities.
6. There are limited resources in many regions that result in understaffed national authorities. This in turn provides the conditions necessary to circumvent national and international regulations. Better implementation of current regulations, including a checks and balances approach as well as strengthening of enforcement is necessary.

As a result of the conclusions drawn above, an EU-level approach is highly recommended to:

(i) shoulder the responsibility in trade of threatened and endemic species not listed in the CITES Appendices,

(ii) regulate trade of CITES Appendix II species when the status is uncertain, and

(iii) pass legislation, in order to protect non-CITES listed, but nationally protected species.

\section{Acknowledgements}

We greatly appreciate support from the following people that provided valuable contacts, information on certain species and issues regarding their trade, in addition to the published literature: Aaron Bauer (Villanova University, USA), Jonathan Campbell (The University of Texas at Arlington), Lee Grismer (La Sierra University, USA), Maurice Isaacs (Ministry of Agriculture, Marine Resources and Local Government, Bahamas), Paula Kahumbu (Wildlife Direct, Kenya), Muhammad Samar Hussain Khan, Assistant Secretary (Wildlife), Ministry of Climate Change (Government of Pakistan), Cendrine Meresse (Direction de l'Environment, New Caledonia), Asghar Mobaraki (Wildlife and Biodiversity Bureau Pardisan Eco-park; CITES Authority Iran), Florentino Chillopa Morales (SEMARNAT, Guatemala), Colum Muccio (Wildlife Rescue and Conservation Association, Guatemala), Mark O'Shea (West Midland Safari Park, United Kingdom), Anslem de Silva (Sri Lanka), Chris R. Shepherd and Sarah Stoner (TRAFFIC Southeast Asia), Peter Paul van Dijk (Global Wildlife Conservation), Bruce Weissgold (U.S. Fish and Wildlife Service) and Beryl Wilson (McGregor Museum, Kimberley, South Africa). We thank Jennifer Weghorst for her careful review of a previous version of the manuscript. Lastly, we offer a special thanks to Ralf Sommerlad, who sadly left us in 2015. Ralf constantly helped us throughout the process of assembling information and writing this paper, and he contributed greatly to this work with his enormous global network of contacts.

\section{References}

ABF, 2015. ABF saves 15 native lizards from illegal export. Press Release by Australian Border Force as of 30th October (http://newsroom.border.gov.au/releases/abf-saves-15native-lizards-from-illegal-export).

ACBPS, 2015. Traffickers attempt to export hundreds of reptiles from WA. Joint Media Release of the Australian Customs and Border Protection Service with WA Department of Parks and Wildlife, Dated 16 February (Available at http://newsroom.border.gov. au/releases/traffickers-attempt-to-export-hundreds-of-reptiles-from-wa).

Adams, W.M., 2014. The value of valuing nature. Science 346, 549-551.

AFFO, A., 2001. Commerce international des Reptiles élevés en captivité au Togo: cas des pythons, tortues et caméléons. Unpublished training report, School for the training of wildlife specialist, Garoua, Cameroon, 1-41.

Alacs, E.A., Janzen, F.J., Scribner, K.T., 2007. Genetic issues in freshwater turtle and tortoise conservation. Chelonian Res. Monogr. 4, 107-123.

Alacs, E., Georges, A., 2008. Wildlife across our borders: a review of the illegal trade in Australia. Aust. J. Forensic Sci. 40, 147-160.

Altherr, S., 2014. Stolen Wildlife - Why the EU Needs to Tackle Smuggling of Nationally Protected Species. Pro Wildlife (Ed.), Munich, Germany (32 pp.).

Amarasinghe, A.A.T., Ineich, I., Karunarathna, D.M.S.S., Botejue, W.M.S., Campbell, P.D., 2015. Two new species of the genus Sitana Cuvier, 1829 (Reptilia: Agamidae) from Sri Lanka, including a taxonomic revision of the Indian Sitana species. Zootaxa 3915, 67-98.

Anderson, C., 2014. The trade status of Rhampholeon spinosus. Chameleons! Online E-Zine, June 2014. www.chameleonnews.com/14JunAnderonSpinosus.html.

Anonymous, 2010a. Sri Lanka to consider reptile exports to Germany. Article in the Sunday Times online. http://www.sundaytimes.lk/101003/BusinessTimes/bt06.html.

Anonymous, 2010b. Lankan reptiles not for export or exploitation, says environmentalist. Article in the Sunday Times online. http://www.sundaytimes.lk/101010/News/nws_ 22.html. 
Anonymus, 2013. Neue Arten braucht das Land: Die Europäische Sumpfschildkröte. ZZA, Zoologischer Zentral Anzeiger. Fachmagazin Heimtierbr. 2013 (5), 62-63.

Anonymous, 2015. This odd world: squeaking crotch foils smuggling attempt. Article in Jakarta post, 19 October 2015. http://www.thejakartapost.com/news/2015/10/19/this-oddworld-squeaking-crotch-foils-smuggling-attempt.html (accessed 21 October 2015).

Anonymous, 2016. Paket Bertuliskan "Mie Ramin", Isinya Biawak Tak Bertelinga. Article in Kompas, 22 March 2016. http://regional.kompas.com/read/2016/03/15/17180021/ Paket.Bertuliskan.Mie.Ramen.Isinya.Biawak.Tak.Bertelinga (accessed 17 March 2016).

Ariano-Sánchez, D., Melendez, L., 2009. Arboreal alligator lizards in the genus Abronia: emeralds from the cloud forests of Guatemala. Rept. Amphibians Conserv. Nat. Hist. $16,25-27$.

Ariano-Sánchez, D., Pasachnik, S., 2013. Ctenosaura palearis. The IUCN Red List of Threatened Species 2013 http://dx.doi.org/10.2305/IUCN.UK.2011-1.RLTS.T44192A108 60487.en.

Ariano-Sánchez, D., Salazar, G., 2015. Spatial ecology of the endangered Guatemalan beaded lizard, Heloderma charlesbogerti, (Sauria: Helodermatidae) in a tropical dry forest of the Motagua Valley, Guatemala. Mesoam. Herpetol. 2, 64-74.

Ariano-Sánchez, D., Torres-Almazán, M., 2010. Rediscovery of Abronia campbelli (Sauria: Anguidae) from a pine-oak forest in southeastern Guatemala: habitat characterization, natural history, and conservation status. Herpetol. Rev. 41, 290-292.

Asian Turtle Trade Working Group, 2000. Chelodina mccordi. The IUCN Red List of Threatened Species 2000: E.T4606A11027770 http://dx.doi.org/10.2305/IUCN.UK.2000. RLTS.T4606A11027770.en (accessed 22 November 2015).

Avila Villegas, H., Frost, D.R., Arnaud, G., 2007. Crotalus catalinensis. The IUCN Red List of Threatened Species 2007: e.T64314A12764544 http://dx.doi.org/10.2305/IUCN.UK. 2007.RLTS.T64314A12764544.en (accessed 10 November 2015).

Auliya, M., 2003. Hot Trade in Cool Creatures: A Review of the Live Reptile Trade in the European Union in the 1990s with a Focus on Germany. TRAFFIC Europe, Brussels.

Baard, E.H.W., de Villiers, A.L., 2000. State of biodiversity: Western Cape Province, South Africa amphibians and reptiles. State of Biodiversity Report 2000. Western Cape Nature Conservation Board.

Bahamas, 2014. Report on the smuggling of Bahamian rock iguanas. Information Document SC65 Inf. 4 for the 66th Meeting of the CITES Standing Committee, 7-11 July 2014, Geneva.

Baling, M., van Winkel, D., Rixon, M., Ruffell, J., Weihong, J., et al., 2013. A review of reptile research and conservation management on Tiritiri Matangi Island, New Zealand. N. Z. J. Ecol. 37, 272-281.

Bartelt, U., de Bitter, H., de Bitter, M., 2005. Lyriocephalus scutatus - the Lyrehead lizard. Reptilia (Barcelona) 42, 29-36.

Bauer, A.M., Sadlier, R.A., 2000. New data on the distribution, status, and biology of the New Caledonian giant geckos (Squamata: Diplodactylidae: Rhacodactylus spp.). Amphibian Rept. Conserv. 2, 24-29.

Bauer, A.M., Jackman, T.R., Sadlier, R.A., Whitaker, A.H., 2012. Revision of the giant geckos of New Caledonia (Reptilia: Diplodactylidae: Rhacodactylus). Zootaxa $3404,1-52$

Behrooz, R., Kaboli, M., Nourani, E., Ahmadi, M., Shabani, A.A., et al., 2015. Habitat modeling and conservation of the endemic Latifi's viper (Montivipera latifii) in Lar National Park, Northern Iran. Herpetol. Conserv. Biol. 10, 572-582.

Bennett, D., Sweet, S.S., 2010. Varanus boehmei. The IUCN Red List of Threatened Species 2010: E.T178267 A7510597 http://dx.doi.org/10.2305/IUCN.UK.2010-4.RLTS T178267A7510597.en (accessed 22 March 2016).

Bennett, D., 2014. A dubious account of breeding Varanus olivaceus in captivity at the paradise reptile zoo in Mindoro, Philippines. Biawak 8, 12-14.

Bertolero, A., Cheylan, M., Hailey, A., Livoreil, B., Willemsen, R.E., 2011. Testudo hermanni (Gmelin 1789) - Hermann's tortoise. Chelonian Res. Monogr. 5, 059.1-059.20. http://dx.doi.org/10.3854/crm.5.059.hermanni.v1.2011.

Böhm, M., Collen, B., Baillie, J.E., Bowles, P., Chanson, J., et al., 2013. The conservation status of the world's reptiles. Biol. Conserv. 157, 372-385. http://dx.doi.org/10.1016/j. biocon.2012.07.015.

Böhme, W., El Din, S.B., 2006. Acanthodactylus pardalis. The IUCN Red List of Threatened Species 2006: e.T61460A12471786 http://dx.doi.org/10.2305/IUCN.UK.2006.RLTS. T61460A12471786.en (accessed 16 November 2015).

Brady, L.D., Griffiths, R.A., 1999. Status Assessment of Chameleons in Madagascar. IUCN Species Survival Commission. IUCN, Gland, Switzerland, Cambridge, UK ( 80 pp. Available at http://ec.europa.eu/environment/cites/pdf/studies/chameleons_en.pdf).

Branch, W.R., Tolley, K.A., Cunningham, M., Bauer, A.M., Alexander, G., et al., 2006. A Plan for Phylogenetic Studies of South African Reptiles: Proceedings of a Workshop Held at Kirstenbosch, February 2006. Biodiversity Series Vol. 5. South African National Biodiversity Institute, Pretoria. http://dx.doi.org/10.5962/bhl.title.66721 (54 pp.).

Brook, B.W., Sodhi, N.S., 2006. Rarity bites. Nature 444, 555-557.

Brook, B.W., Sodhi, N.S., Bradshaw, C.J., 2008. Synergies among extinction drivers under global change. Trends Ecol. Evol. 23, 453-460. http://dx.doi.org/10.1016/j.tree.2008. 03.011.

Brown, R.M., Siler, C.D., Oliveros, C.H., Welton, L.J., Rock, A., et al., 2013. The amphibians and reptiles of Luzon Island, Philippines, VIII: the herpetofauna of Cagayan and Isabela provinces, northern Sierra Madre Mountain Range. Zookeys 266, 1-120.

Buffrénil, V.D., 1995. Les élevages de reptiles du Bénin, du Ghana et du Togo. Report to the Secretariat of the Convention on International Trade in Endangered Species of Wild Fauna and Flora (CITES), Lausanne.

Bush, E.R., Baker, S.E., Macdonald, D.W., 2014. Global trade in exotic pets 2006-2012. Conserv. Biol. 28, 663-676. http://dx.doi.org/10.1111/cobi.12240.

Buskirk, J.R., 1989. A third specimen and neotype of Heosemys leytensis (Chelonia: Emydidae). Copeia 1989, 224-227.

Carpenter, A.I., Rowciffe, J.M., Watkinson, A.R., 2004. The dynamics of the global trade in chameleons. Biol. Conserv. 120, 291-301. http://dx.doi.org/10.1016/j.biocon.2004.03. 002 .
Ceballos, G., Ehrlich, P.R., Barnosky, A.D., García, A., Pringle, R.M., et al., 2015. Accelerated modern human-induced species losses: entering the sixth mass extinction. Sci. Adv. 1, 1-5, e1400253. http://dx.doi.org/10.1126/sciadv.1400253.

Chapman, A., 2009. Numbers of living species in Australia and the world. Australian Biodiversity Information Services, Toowoomba, Australia. A Report for the Australian Biological Resources Study September 2009 (Available at www.environment.gov.au/ node/13867).

Cheung, S.M., Dudgeon, D., 2006. Quantifying the Asian turtle crisis: market surveys in southern China, 2000-2003. Aquat. Conserv. Mar. Freshwat. Ecosyst. 16 751-770.

Choudhury, B.C., Bhupathy, S., 1993. Turtle Trade in India, a Study of Tortoise and Fresh Water Turtles. Traffic India/WWF, India.

Christy, B., 2008. The Lizard King - The True Crimes and Passions of the World's Greates Reptile Smugglers. Hachette Book Group, New York.

CONAP, 2011. Base de Datos de Animales Confiscados en Aeropuerto Internacional La Aurora, Guatemala

Cooney, R., Kasterine, A., MacMillan, D., Milledge, S., Nossal, K., et al., 2015. The Trade in Wildlife: A Framework to Improve Biodiversity and Livelihood Outcomes. International Trade Centre, Geneva (https://www.cbd.int/financial/monterreytradetech/ iucn-wildtrade.pdf).

Costanza, R., d'Arge, R., de Groot, R., Farberk, S., Grasso, M., et al., 1997. The value of the world's ecosystem services and natural capital. Nature 387, 253-260. http://dx.doi. org/10.1038/387253a0

Cotí, P., Ariano-Sánchez, D., 2008. Ecology and traditional use of the Guatemalan black iguana (Ctenosaura palearis) in the dry forests of the Motagua Valley, Guatemala. Iguana 15, 42-149.

Courchamp, F., Angulo, E., Rivalan, P., Hall, R.J., Signoret, L., et al., 2006. Rarity value and species extinction: the anthropogenic Allee effect. PLoS Biol. 4, e415. http://dx.doi org/10.1371/journal.pbio.0040415.

Crandall, K.A., 2009. A multifaceted approach to species conservation. Anim. Conserv. 12 105-106. http://dx.doi.org/10.1111/j.1469-1795.2009.00254.x.

Cree, A., 1994. Low annual reproductive output in female reptiles from New Zealand. N. Z J. Zool. 21, 351-372.

Dalton, R., 2003. Mock turtles. Nature 423, 219-220. http://dx.doi.org/10.1038/ 423219a.

Daugherty, C.H., Gibbs, G.W., Hitchmough, R.A., 1993. Mega-island or micro-continent? New Zealand and its fauna. Trends Ecol. Evol. 8, 437-442. http://dx.doi.org/10. 1016/0169-5347(93)90006-B.

D'Cruze, N., Singh, B., Morrison, T., Schmidt-Burback, J., Macdonald, D.W., et al., 2015. A star attraction: the illegal trade in Indian star tortoises. Nat. Conserv. 13, 1-19. http://dx.doi.org/10.3897/natureconservation.13.5625.

Department of the Environment, 2015. Exporting Live Australian Native Plants and Animals. Website of the Australian Government (https://www.environment.gov.au/ biodiversity/wildlife-trade/natives - accessed 15 July 2015).

Diesmos, A.C., Gee, G.V., Diesmos, M.L., Brown, R.M., Widmann, P.J., et al., 2004. Rediscovery of the Philippine forest turtle Heosemys leytensis (Chelonia: Bataguridae), from Palawan Island, Philippines. Asiat. Herpetol. Res. 10, 22-27.

Diesmos, A.C., Brown, R.M., Alcala, A.C., Sison, R.V., 2008. Status and distribution of nonmarine turtles of the Philippines. Chelonian Conserv. Biol. 7, 157-177.

Diesmos, A.C., Buskirk, J.R., Schoppe, S., Diesmos, M.L., Sy, E.Y., et al., 2012 Siebenrockiella leytensis (Taylor 1920) - Palawan forest turtle, Philippine forest turtle Chelonian Res. Monogr. 5, 066.1-066.9. http://dx.doi.org/10.3854/crm.5.066. leytensis.v1.2012.

Dirzo, R., Raven, P.H., 2003. Global state of biodiversity and loss. Annu. Rev. Environ. Resour. 28, 137-167. http://dx.doi.org/10.1146/annurev.energy.28.050302.105532.

Engler, M., Parry-Jones, R., 2007. Opportunity or Threat: The Role of the European Union in Global Wildlife Trade. TRAFFIC Europe, Brussels.

Eurostat, 2015. Import data for live reptiles (commodity group number 01062000 ) to EU member states, period 2004-2014. http://epp.eurostat.ec.europa.eu/portal/page/ portal/statistics/search_database.

Fernando, J.A., 2010. Sri Lanka needs to revise reptile export rules: European reptile breeder. Asian tribune, online http://www.asiantribune.com/news/2010/11/14/srilanka-needs-revise-reptile-export-rules-european-reptile-breeder.

Flecks, M., Weinsheimer, F., Böhme, W., Chenga, J., Lötters, S., et al., 2012. Watching extinction happen: the dramatic population decline of the critically endangered Tanzanian turquoise dwarf gecko, Lygodactylus williamsi. Salamandra 48, 23-31.

Flores-Villela, O., García-Vázquez, U.O., 2014. Biodiversidad de reptiles en México. Rev. Mex. Biodivers. 85, 467-475. http://dx.doi.org/10.7550/rmb.43236.

Fong, J.J., Parham, J.F., Fu, J., 2002. A reassessment of the distribution of Cuord flavomarginata Gray 1863 on mainland China. Russ. J. Herpetol. 9, 9-14.

Gavino, C.M., Schoppe, S., 2004. First information on the trade of freshwater turtles in Palawa. Agham Mindanaw, Ateneo Davao J. Sci. Technol. 2, 53-60.

Gentile, G., Ciambotta, M., Aguillera, W.T., 2013. Illegal wildlife trade in Galápagos: molec ular tools help the taxonomic identification of confiscated iguanas and guide thei rapid repatriation. Conserv. Genet. Resour. 5, 867-872. http://dx.doi.org/10.1007/ s12686-013-9915-7.

Gibbons, J.W., Scott, D.E., Ryan, T.J., Buhlmann, T.D., Metts, B.S., et al., 2000. The global decline of reptiles, déjà vu amphibians. Bioscience 50, 653-666. http://dx.doi.org/10 1641/0006-3568(2000)050[0653:TGDORD]2.0.C.

Gomar, J.O., Stringer, L.C., 2011. Moving towards sustainability? An analysis of CITES' conservation policies. Environ. Policy Govern. 21, 240-258. http://dx.doi.org/10.1002 eet.577.

Gong, S.P., Chow, A.T., Fong, J.J., Shi, H.T., 2009. The chelonian trade in the largest pet market in China: scale, scope and impact on turtle conservation. Oryx 43, 213-216.

Gong, S.P., Yang, D.-D., Chen, Y.-H., Lau, Wang, F.-M., 2013. Population status, distribution and conservation needs of the endangered Mangshan pit viper Protobothrops 
mangshanensis of China. Oryx 47, 122-127. http://dx.doi.org/10.1017/ S0030605311001037.

Goode, M.J., Swann, D.E., Schwalbe, C.R., Mannan, R.W., 1998. The Effects of Microhabitat Destruction on Reptile Abundance. Nongame and Endangered Wildlife Program Heritage Report. Arizona Game and Fish Department, Phoenix, Arizona.

Goode, M.J., Swann, D.E., Schwalbe, C.R., 2004a. Effects of destructive collecting practices on reptiles: a field experiment. J. Wildl. Manag. 68, 429-434.

Goode, M.J., Horrace, W.C., Sredl, M.J., Howland, J.M., 2004b. Habitat destruction by collectors associated with decreased abundance of rock-dwelling lizards. Biol. Conserv. 125, 47-54. http://dx.doi.org/10.1016/j.biocon.2005.03.010

Grismer, L.L., Viets, B.E., Boyle, L.J., 1999. Two new continental species of Goniurosaurus (Squamata: Eublepharidae) with a phylogeny and evolutionary classification of the genus. J. Herpetol. 33, 382-393.

Grismer, L., 2002. Amphibians and Reptiles of Baja California: Including its Pacific Islands and the Islands of the Sea of Cortes. University of California Press, Berkeley, Los Angeles, London.

Grismer, L.L., Tri, N.V., Grismer, J.L, 2008. A new species of insular pitviper of the genus Cryptelytrops (Squamata: Viperidae) from southern Vietnam. Zootaxa 1715, 57-68.

Grismer, L.L., Ngo, V.T., Grismer, J.L., 2010. A new colorful new species of insular rock gecko (Cnemaspis Strauch 1887) from southern Vietnam. Zootaxa 2352, 46-58. http://dx.doi.org/10.11646/zootaxa.3755.5.4

Gruttke, H., 2004. Ermittlung der Verantwortlichkeit für die Erhaltung mitteleuropäische Arten. Referate und Ergebnisse des Symposiums auf der Insel Vilm vom 17-20. November 2003. Bundesamt für Naturschutz (Ed.), Naturschutz und Biologische Vielfalt, Bonn-Bad Godesberg.

Hall, R.J., Milner-Gulland, E.J., Courchamp, F., 2008. Endangering the endangered: the effects of perceived rarity on species exploitation. Conserv. Lett. 1, 75-81. http://dx. doi.org/10.1111/j.1755-263X.2008.00013.x.

Harris, M., 2002. Assessment of the status of seven reptile species in Togo. Report to the Commission of the European Union, Réf. EC 9810072, 1-58 + 1-6 (Available at http://jncc.defra.gov.uk/pdf/togo_sevenreptilespeciesvpt1.pdf).

Harwood, J., 2003. West African reptiles: species status and management guidelines for reptiles in international trade from Benin and Togo. Report to the European Commission Prepared for the European Commission, Directorate General E Environment, ENV E.3 - Development and Environment, January 2003, UNEPWCMC: I-v + 1-51.

Henle, K., Bauch, B., Auliya, M., Külvik, M., Pe'er, G., et al., 2013. Priorities for biodiversity monitoring in Europe: a review of supranational policies and a novel scheme for integrative prioritization. Ecol. Indic. 33, 5-18. http://dx.doi.org/10.1016/j.ecolind.2013. 03.028 .

Herbig, J., 2011. The illegal reptile trade as a form of conservation crime: a South African criminological investigation. In: White, R. (Ed.), Global Environmental Harm - Criminological Perspectives. Routledge, New York, pp. 110-131.

Herpetological Society of Japan, 2013. List of Japanese reptile species and standard Japanese nomenclature (in Japanese). (Available at:) http://zoo.zool.kyoto-u.ac.jp/herp/ wamei.html (accessed 4 July 2014).

Hettiarachchi, K., 2010. EDB tries to take sting out of reptile export controversy. The Sunday Times online. http://sundaytimes.lk/101017/News/nws_24.html (accessed 5 October 2014).

Hettiarachchi, K., Daniel, S., 2011. Spiriting out endemic species. The Sunday Times online. http://www.sundaytimes.lk/110710/Plus/plus_02.html (accessed 14 September 2014)

Hettige, P., 2011. Action against smuggling of reptiles. The island, online. http://www. island.lk/index.php?page_cat $=$ article-details\&page $=$ article-details\&code_title $=$ 23361 (accessed 19 May 2014)

Hitchmough, R., Anderson, P., Barr, B., Hoare, J., Lettink, M., et al., 2013. Conservation status of New Zealand reptiles, 2012. New Zealand Threat Classification System Series. Department of Conservation, Wellington (http://www.doc.govt.nz/Documents/ science-and-technical/nztcs2entire.pdf - accessed 7 January 2014).

Hoffmann, M., Brooks, T.M., da Fonseca, G.A.B., Gascon, C., Hawkins, A.F.A., et al., 2008. Conservation planning and the IUCN Red List. Endanger. Species Res. 6, 113-125. http://dx.doi.org/10.3354/esr00087.

Hollingsworth, B., Frost, D.R., 2007. Lampropeltis herrerae. The IUCN Red List of Threatened Species 2007: e.T63829A12720145 http://dx.doi.org/10.2305/IUCN.UK.2007.RLTS. T63829A12720145.en (accessed 10 November 2015).

Hoover, C. 1998. The U.S. Role in the International Live Reptile Trade: Amazon Tree Boa to Zululand Dwarf Chameleons. TRAFFIC North America, Washington, D.C.

Horne, B.D., Poole, C.M., Walde, A.D., 2011. Conservation of Asian Tortoises and Freshwater Turtles: Setting Priorities for the Next Ten Years Recommendations and Conclusions from the Workshop in Singapore, February 21-24, 2011

Huang, C.M., Yu, H., Wu, Z., Li, Y.B., Wei, F.W., et al., 2008. Population and conservation strategies for the Chinese crocodile lizard (Shinisaurus crocodilurus) in China. Anim. Biodivers. Conserv. 31, 63-70.

Ineich, I., 2006. Les élevages de reptiles et de scorpions au Bénin, Togo et Ghana, plus particulièrement la gestion des quotas d'exportation et la définition des codes 'source' des spécimens exportés. Rapport d'étude réalisée Pour le Secrétariat de la CITES, Projet CITES A-251, pp. 1-113.

IUCN, 2015. The IUCN Red List of threatened species. (Version 2015-3) http://www iucnredlist.org (accessed 9 September 2015).

Japan Customs, 2014. Trade statistics. (downloaded at:) http://www.customs.go.jp/ toukei/info/index.htm (on 2014/07/05)

Jenkins, R.W., 1998. Management and use of Python regius in Benin and Togo. Report Prepared for Directorate General XI. The Commission of the European Union, pp. 1-11 (doc. SRG 8/5/3).

Jenkins, R.K., Tognelli, M.F., Bowles, P., Cox, N., Brown, J.L., et al., 2014. Extinction risks and the conservation of Madagascar's reptiles. PLoS One 9, e100173. http://dx.doi.org/10. 1371/journal.pone.0100173.
Kabigumila, J., 1998. Efficacy of leopard tortoise (Geochelone pardalis babcocki) farming in Tanzania. Afr. Stud. Monogr. 19, 1187-1200.

Kanari, K., 2010. Trade in live reptiles as pets. The State of Wildlife Trade in Japan. TRAFFIC East Asia, Japan. Tokyo, pp. 14-17.

Kanari, K., Auliya, M., 2011. The reptile pet trade of Japan. Internal Report to TRAFFIC East Asia, Tokio.

Kanari, K., Xu, L., 2012. Trade in Japanese Endemic Reptiles in China and Recommendations for Species Conservation. TRAFFIC East Asia, Tokio.

Karunarathna, D.M., Amarasinghe, A.A., 2013. Behavioral ecology and microhabitat use by Lyriocephalus scutatus (Linnaeus, 1758): a monotypic genus in Sri Lanka (Reptilia: Agamidae: Draconinae) with notes on the taxonomy. Russ. J. Herpetol. 20, 1-15.

Klemens, M.W., Moll, D., 1995. An assessment of the effects of commercial exploitation on the pancake tortoise, Malacochersus tornieri, in Tanzania. Chelonian Conserv. Biol. 1, $197-206$.

Knox, C.D., 2010. Habitat requirements of the jewelled gecko (Naultinus gemmeus): effects of grazing, predation and habitat fragmentation. Unpublished MSc Thesis, University of Otago, Dunedin. $94 \mathrm{pp}$.

Koch, A., Ziegler, T., Böhme, W., Arida, E., Auliya, M., 2013. Pressing problems: distribution, threats, and conservation status of the monitor lizards (Varanidae: Varanus spp.) of Southeast Asia and the Indo-Australian Archipelago. Herpetol. Conserv. Biol. 8 (Monograph 3), 1-62.

Köhler, G., 2008. Reptiles of Central America. second ed. Herpeton, Offenbach.

Kriebel, D., Tickner, J., Epstein, P., Lemons, J., Levins, R., et al., 2001. The precautionary principle in environmental science. Environ. Health Perspect. 109, 871-876.

Lambert, M.R., 1969. Tortoise drain in Morocco. Oryx 10, 161-166. http://dx.doi.org/10. $1017 /$ S0030605300008164.

Leader-Williams, N., 2002. When is international trade in wild animals detrimental to survival: principles, avoidance and monitoring? In: Rosser, A., Haywood, M. (Eds.), Guidance for CITES Scientific Authorities. Checklist to Assist in Making Non-detriment Findings for Appendix II ExportsOccasional Paper of the IUCN Species Survival Commission No. 27. IUCN - The World Conservation Union, Gland, Switzerland

Lenzen, M., Moran, D., Kanemoto, K., Foran, B., Lobefaro, et al., 2012. International trade drives biodiversity threats in developing nations. Nature 486, 109-112. http://dx. doi.org/10.1038/nature11145.

Lettink, M., 2010. Impact report: illegal collection of New Zealand jewelled geckos from the wild for export. Unpublished Report, Wildlife Enforcement Group, Auckland.

Litzgus, J.D., Mousseau, T.A., 2004. Demography of a southern population of the spotted turtle (Clemmys guttata). Southeast. Nat. 3, 391-400. http://dx.doi.org/10.1656/ 1528-7092(2004)003[0391:DOASPO]2.0.CO;2.

Lovich, R.E., Grismer, L., Danemann, G., 2009. Conservation status of the herpetofauna of Baja California, México and Associated Islands in the sea of Cortez and Pacific Ocean. Herpetol. Conserv. Biol. 4, 358-378.

Luiselli, L., Bonnet, X., Rocco, M., Amori, G., 2012. Conservation implications of rapid shifts in the trade of wild African and Asian pythons. Biotropica 44, 569-573. http://dx.doi. org/10.1111/j.1744-7429.2011.00842x.

Luiselli, L., Diagne, T., 2013. Kinixys homeana Bell 1827 - home's hinge-back tortoise. Chelonian Res. Monogr. 5, 070.1-070.10. http://dx.doi.org/10.3854/crm.5.070.homeana. v1.2013.

Luiselli, L., Petrozzi, F., Akani, G.C., 2013. Long-term comparison reveals trends in turtle trade in bushmeat markets of southern Nigeria. Herpetozoa 26, 57-64.

Lutz, M., 2006. Der Butaan (Varanus olivaceus), Hallowell 1856, Haltung und erste erfolgreiche Nachzucht im Terrarium. Sauria 28, 5-13.

Lyons, J.A., Natusch, D.J., 2011. Wildlife laundering through breeding farms: illegal harvest, population declines and a means of regulating the trade of green pythons (Morelia viridis) from Indonesia. Biol. Conserv. 144, 3073-3081. http://dx.doi.org/ 10.1016/j.biocon.2011.10.002.

Lyons, J.A., Natusch, D.J., 2013. Effects of consumer preferences for rarity on the harvest of wild populations within a species. Ecol. Econ. 93, 278-283. http://dx.doi.org/10.1016/ jecolecon.2013.06.004.

Machado, A., López-Jurado, L.F., Martín, A., 1985. Conservation status of reptiles in the Canary Islands. Bonn. Zool. Beitr. 36, 585-606.

Menagh, J., 2015. European reptile smugglers on 'scientific endeavour' in WA avoid further jail time but likely face deportation. Article in ABC News 17 Sep 2015.

Menegon, M., Davenport, T., Howell, K., 2011. Description of a new and critically endangered species of Atheris (Serpentes: Viperidae) from the southern highlands of Tanzania, with an overview of the country's tree viper fauna. Zootaxa $3120,43-54$

Meijaard, E., Nijman, V., 2014. Secrecy considerations for conserving Lazarus species. Biol. Conserv. 175, 21-24. http://dx.doi.org/10.1016/j.biocon.2014.03.021.

Ministry of Environment, 2012. The National Red List 2012 of Sri Lanka; Conservation Status of the Fauna and Flora. Colombo, Sri Lanka.

Mittermeier, R.A., Myers, N., Thomsen, J.B., da Fonseca, G.A.B., Olivieri, S., 1998. Biodiversity hotspots and major tropical wilderness areas: approaches to setting conservation priorities. Conserv. Biol. 12, 516-520.

Mittermeier, R.A., Mittermeier, C.G., 2004. Megadiversity: Earth's biologically Wealthiest Nations. Graphic Arts Center Publishing Company, Portland.

Mobaraki, A. Mohsen Amiri, M. Alvandi, R. Tehrani, M.E, Kia, H. Z et al, 2013. A conservation reassessment of the critically endangered, Lorestan newt Neurergus kaiseri (Schmidt 1952) in Iran. Amphibian Rept. Conserv. 9, 1-8.

Myers, N., Mittermeier, R.A., Mittermeier, C.G., da Fonseca, G.A., Kent, J. 2000. Biodiversity hotspots for conservation priorities. Nature 403, 853-858. http://dx.doi.org/10.1038/ 35002501.

Nash, S.V., 1993. Problems with the Implementation of CITES Article IV in Southeast Asia - Review No. 1: Indonesia. TRAFFIC Southeast Asia. 
Natusch, D., Lyons, J., 2012. Exploited for pets: the harvest and trade of amphibians and reptiles from Indonesian New Guinea. Biodivers. Conserv. 21, 2899-2911. http://dx doi.org/10.1007/s10531-012-0345-8.

Nguyen, T.Q., Hamilton, P., Ziegler, T., 2014. Shinisaurus crocodilurus. The IUCN Red List of Threatened Species 2014: e.T57287221A57287235 http://dx.doi.org/10.2305/IUCN. UK.2014-1.RLTS.T57287221A57287235.en (accessed October 2014).

Nijman, V., Shepherd, C.R., 2009. Wildlife trade from ASEAN to the EU: issues with the trade in captive-bred reptiles from Indonesia. TRAFFIC Europe Report for the European Commission, Brussels, Belgium.

Nijman, V., Stoner, S.S., 2014. Keeping an ear to the ground: monitoring the trade in Earless Monitor Lizards. TRAFFIC (Ed.), Petaling Jaya, Malaysia.

Nijman, V., Shepherd, C.R., Mumpuni, Sanders, K., 2012. Over-exploitation and illegal trade of reptiles in Indonesia. Herpetol. J., 22, 83-89.

Nilson, G., Andrén, C., Flärdg, B., 1990. Vipera albizona, a new mountain viper from central Turkey, with comments on isolating effects of the Anatolian "diagonal". AmphibiaReptilia 11, 285-294.

Nilson, G., Andrén, C., 1999. Lessons to be learned from the conservation of endangered vipers. In: Johnson, B., Wright, M. (Eds.), Second International Symposium and Workshop on the Conservation of the Eastern Massasauga Rattlesnake, Sistrurus catenatus catenatus: Population and Habitat Management Issues in Urban, Bog, Prairie and Forested Ecosystems. Toronto Zoo, Toronto, Ontario, pp. 9-13.

Nilson, G., 2009. Montivipera albicornuta. The IUCN Red List of Threatened Species 2009: e.T164717A5920222 http://dx.doi.org/10.2305/IUCN.UK.2009.RLTS.T164717A5920222. en (accessed 22 November 2015).

Orlov, N., Ryabov, S., Nguyen, T., Nguyen, T., 2010. Rediscovery and Redescription of two rare snake species: Oligodon lacroixi Angel et Bourret, 1933 and Maculophis bellus chapaensis (Bourret, 1934) [Squamata: Ophidia: Colubridae] from Fansipan Mountains, northern Vietnam. Russ. J. Herpetol. 17, 310-322.

Palihawardana, A., 1996. An ecological study of the Cophotis ceylanica. In: Amphibian and Reptile Research Organisation of Sri Lanka, Kandy, Sri Lanka (Ed.): Biology and Conservation of the Amphibians, Reptiles and their Habitats in South Asia. pp. 253-260.

Paranamanna, L., 2011. EDB snake plan stings ecologists Daily Mirror online. http://print2. dailymirror.lk/news/front-page-news/23372.html (accessed 10 December 2013).

Parham, J.F., Li, D., 1999. A new locality for Cuora pani Song 1984 with comments on its known range. Asiat. Herpetol. Res. 8, 111-113.

Parham, J.F., Simison, W.B., Kozak, K.H., Feldman, C.R., Shi, H., 2001. New Chinese turtles: Endangered or invalid? A reassessment of two species using mitochondrial DNA allozyme electrophoresis, and known locality specimens. Anim. Conserv. 4, 357-367.

Parham, J.F., Stuart, B.L., Bour, R., Fritz, U., 2004. Evolutionary distinctiveness of the extinct Yunnan box turtle, Cuora yunnanensis, revealed by DNA from an old museum specimen. Biol. Lett. 271, 391-394.

Pasachnik, S.A., 2013. Growth, reproduction and diet Roatan spiny-tailed iguanas, Ctenosaura oedirhina. Herpetol. Conserv. Biol. 8, 191-198.

Pedrono, M., 2008. The Tortoises and Turtles of Madagascar. Natural History Publications (Ed.), Borneo, Kota Kinabalu, Malaysia.

Pedrono, M., 2011. Wasted efforts: why captivity is not the best way to conserve species. Madagascar Conserv. Dev. 6, 57-59.

Perälä, J., 2003. Testudo kleinmanni. The IUCN Red List of Threatened Species 2003: e.T21652A9306908 http://dx.doi.org/10.2305/IUCN.UK.2003.RLTS.T21652A9306908. en (accessed 22 November 2015).

Pethiyagoda, R., Manamendra-Arachchi, K., 1998. A revision of the endemic Sri Lankan agamid lizard genus Ceratophora Gray, 1835, with description of two new species. J. S. Asian Nat. Hist. 3, 1-50.

Pimm, S.L., Russell, G.L., Gittleman, J.L., Brooks, T.M., 1995. The future of biodiversity. Science 269, 347-350. http://dx.doi.org/10.1126/science.269.5222.347.

Perry, K., 2014. Stuffed in socks: 13 iguanas smuggled into UK in a suitcase. The telegraph, article of 3rd April. http://www.telegraph.co.uk/news/uknews/crime/10742348/ Stuffed-in-socks-13-iguanas-smuggled-into-UK-in-a-suitcase.html (accessed April 2014)

Porras, L.W., 1999. Island boa constrictors (Boa constrictor). Rept. Mag. 7, 48-61.

Proença, V., Pereira, H.M., 2013. Comparing extinction rates: past, present, and future. Encycl. Biodivers. 2. http://dx.doi.org/10.1016/B978-0-12-384719-5.00411-1.

Rastegar-Pouyani, N., Gholamifard, A., Karamiani, R., Bahmani, Z., Mobaraki, A., et al., 2015. Sustainable management of the herpetofauna of the Iranian Plateau and coastal Iran. Amphibian Rept. Conserv. 9, 1-15.

Razafimahatratra, B., Razafimanjato, G., Thorstrom, R., 2010. A new locality for the endangered day gecko Phelsuma klemmeri from western Madagascar. Herpetol. Notes 3 , 197-199.

Raxworthy, C.J., Ratsoavina, F., Rabibisoa, N., Rakotondrazafy, N.A., Bora, P., 2011. Paroedura lohatsara. The IUCN Red List of Threatened Species 2011: e.T172883A6935268 http:// dx.doi.org/10.2305/IUCN.UK.2011-2.RLTS.T172883A6935268.en.

Reading, C.J., Luiselli, L., Akani, G.C., Bonnet, X., Amori, G., et al., 2010. Are snake populations in widespread decline? Biol. Lett. 6, 777-780. http://dx.doi.org/10.1098/rsbl. 2010.0373 .

Reed, R.N., Boback, S.M., Montgomery, C.E., Green, S., Stevens, Z., et al., 2007. Ecology and conservation of an exploited insular population of Boa constrictor (Squamata: Boidae) on the Cayos Cochinos, Honduras. In: Henderson, R.W., Powell, R. (Eds.), Biology of the Boas and Pythons. Eagle Mountain Publishing, Eagle Mountain, Utah, pp. 389-403.

Reznick, D., Bryant, M.J., Bashey, F., 2002. R- and K-selection revisited: the role of population regulation in life history evolution. Ecology 83, 1509-1520. http://dx.doi.org/10. 1890/0012-9658.

Rivalan, P., Delmas, V., Angulo, E., Bull, L.S., Hall, R.J., et al., 2007. Can bans stimulate wildlife trade? Nature 447, 529-530.

Robinson, J.E., Griffiths, R.A., St. John, F.A.V., Roberts, D.L., 2015. Dynamics of the global trade in live reptiles: shifting trends in production and consequences for sustainability. Biol. Conserv. 184, 42-50. http://dx.doi.org/10.1016/j.biocon.2014.12.019.
Rodrigo, M., 2012. Wildlife officers raid Kalpitiya hotel, arrest six tourists, seize protected wildlife species. The Sunday Times, online. http://www.sundaytimes.lk/120304/ News/nws_44.html (accessed February 2013).

Rosa, G., Noël, J., Andreone, F., 2011. Confirming a new population of the endangered Paroedura masobe (Squamata: Gekkonidae) in the relict Betampona low elevation rainforest, eastern Madagascar. Herpetol. Notes 4, 405-407.

Rosen, G.E., Smith, K.F., 2010. Summarizing the evidence on the international trade in illegal wildlife. EcoHealth 7, 24-32. http://dx.doi.org/10.1007/s10393-010-0317-y.

Schlaepfer, M.A., Hoover, C., Dodd, K., 2005. Challenges in evaluating the impact of the trade in amphibians and reptiles on wild populations. Bioscience 55, 256-264. http://dx.doi.org/10.1641/0006-3568(2005)055[0256:CIETIO]2.0.CO.

Schmeller, D.S., Evans, D., Lin, Y.P., Henle, K., 2014. The national responsibility approach to setting conservation priorities - recommendations for its use. J. Nat. Conserv. 22, 349-357. http://dx.doi.org/10.1016/j.jnc.2014.03.002.

Schneeweiss, N., Hintzmann, J., Lippert, J., Stein, M., Thiesmeier, B., 2014. Amphibien- und Reptilienhandel als Gefährdungsfaktor für heimische Populationen. Z. Feldherpetol. 21, 101-120.

Schoppe, S., Cervancia, M., 2009. Herpetological surveys along the Pagdanan Range and Dumaran Island, northern Palawan, Philippines. Hamadryad 34, 95-106.

Schoppe, S., Shepherd, C., 2013. The Palawan forest turtle under threat from internationa trade. TRAFFIC Bull. 25, 9-11.

Schoppe, S., Matillano, J., Cervancia, M., Acosta, D., 2010. Conservation needs of the critically endangered Philippine forest turtle Siebenrockiella leytensis (Taylor, 1920) in Palawan. Chelonian Conserv. Biol. 9, 145-153.

Schütz, C., 2003. Transport losses of CITES-protected and non-protected animal species. Bundesamt für Naturschutz (Ed.), BfN Skripten 90. BfN (Federal Agency for Nature Conservation), Bonn.

Segniagbeto, H., 2009. Herpétofaune du Togo: Taxinomie, Biogéographie (Thèse de doctorat) Univ. Lomé (Togo) and MNHN, Paris (France) (Tome I, 1-172 and Tome II, 1-192).

Sekhar, A.C., Gurunathan, N., Anandhan, G., 2004. Star tortoise - a victim of the exotic pet trade. Tigerpaper 31, 4-6.

Sellar, J., 2014. Policing the trafficking of wildlife: is there anything to learn from law enforcement responses to drug and firearms trafficking? Report of the Global Initiative Against Transnational Organized Crime Series on Environmental Crime (Available at http://www.globalinitiative.net/download/global-initiative/Global\%20Initiative\% 20-\%20Wildlife\%20Trafficking\%20Law\%20Enforcement\%20-\%20Feb\%202014.pdf)

SEMARNAT (Secretaría de Medio Ambiente y Recursos Naturales), 2010e. NORMA Oficia Mexicana NOM-059-SEMARNAT-2010, Protección ambiental-especies nativas de México de flora y fauna silvestres-Categorías de riesgo y especificaciones para su inclusión, exclusión o cambio-Lista de especies en riesgo. (Available at:) http://dof.gob. $\mathrm{mx} /$ nota_detalle_popup.php?codigo $=5173091$.

SEMARNAT (Secretaría de Medio Ambiente y Recursos Naturales), 2015e. Export, import capture and breeding of Ctenosaura species in Mexico 2000-2015. Data Provided through INFOMEX. OFICIO NO. UCPAST/UE/15/2252, 9 OCT. 2015.

Shepherd, C.R., Burgess, E.A., Loo, M., 2004. Demand Driven: The Trade of Indian Star Tortoises Geochelone elegans in Peninsular Malaysia. TRAFFIC Southeast Asia, Petaling Jaya.

Shepherd, C.R., Ibarrondo, B., 2005. The Trade of the Roti Island Snake-Necked Turtle Chelodina mccordi. TRAFFIC Southeast Asia.

Shepherd, C., Nijman, V., 2007. An Overview of the Regulation of the Freshwater Turtle and Tortoise Pet Trade in Jakarta, Indonesia. TRAFFIC Southeast Asia Petaling Jaya.

Shepherd, C.R., Nijman, V., 2008. Pet Freshwater Turtle and Tortoise Trade in Chatuchak Market, Bangkok, Thailand. TRAFFIC Southeast Asia, Petaling Jaya.

Shi, Zhiyong, F., Feng, Y., Zhigang, Y., 2004. New data on the trade and captive breeding of turtles in Guangxi Province, South China. Asiat. Herpetol. Res. 10, 126-128.

Shi, H., Parham, J.F., Lau, M., Chen, T.H., 2007. Farming endangered turtles to extinction in China. Conserv. Biol. 21, 5-6. http://dx.doi.org/10.1111/j.1523-1739.2006.00622 2.x.

Shi, H., Parham, J.F., Fan, Z., Hong, M., Yin, F., 2008. Evidence for the massive scale of turtle farming in China. Oryx 42, 147-150. http://dx.doi.org/10.1017/S0030605 308000562.

Shiau, T.W., Hou, P.C., Wu, S.H., Tu, M.-C., 2006. A survey on alien pet reptiles in Taiwan. Taiwania 51, 71-80.

Siler, C.D., Fuiten, A.M., Jones, R.M., Alcala, A.C., Brown, R.M., 2011. Phylogeny-based species delimitation in Philippine slender skinks (Reptilia: Squamata: Scincidae) II: taxonomic revision of Brachymeles samarensis and description of five new species. Herpetol. Monogr. 25, 76-112.

Siler, C.D., Swab, J.C., Oliveros, C.H., Diesmos, A.C., Averia, L., et al., 2012. Amphibians and reptiles, Romblon Island Group, central Philippines: comprehensive herpetofaunal inventory. Check List 8, 443-462.

Siler, C.D., Linkem, C.W., Cobb, K., Watters, J.L., Cumings, S., et al., 2014. Taxonomic revision of the semi-aquatic skink Parvoscincus leucospilos (Reptilia: Squamata: Scincidae), with description of three new species. Zootaxa 3847, 388-412.

Smith, M.J., Benítez-Díaz, H., Clemente-Muñoz, M.Á., Donaldson, J., Hutton, J.M., et al., 2011. Assessing the impacts of international trade on CITES-listed species: current practices and opportunities for scientific research. Biol. Conserv. 144, 82-91.

Smith, J.W., 2011. Stolen World - A Tale of Reptiles, Smugglers, and Skullduggery. Crown Publishers, New York.

Somaweera, R., Somaweera, N., 2009. Lizards of Sri Lanka: A Colour Guide with Field Keys. Chimaira Buchhandelsgesellschaft $\mathrm{GmbH}$, Frankfurt a. M.

Somaweera, R., Wijayathilaka, N., Bowatte, G., Meegaskumbura, M., 2015. Conservation in a changing landscape: habitat occupancy of the critically endangered Tennent's leafnosed lizard (Ceratophora tennentii) in Sri Lanka. J. Nat. Hist. 49, 1961-1985. http:// dx.doi.org/10.1080/00222933.2015.1006280. 
Spellerberg, I.F., 1976. The amphibian and reptile trade with particular reference to collecting Europe. Biol. Conserv. 10, 221-232. http://dx.doi.org/10.1016/00063207(76)90036-7.

Stanley, E.L., Bauer, A.M., Jackman, T.R., Mouton, P.L.N., Branch, W.R., 2011. Between a rock and a hard polytomy: rapid radiation in the rupicolous girdled lizards (Cordylidae: Squamata). Mol. Phylogenet. Evol. 58, 53-70. http://dx.doi.org/10.1016/j.ympev. 2010.08.024.

Steinmetz, M., Pütsch, M., Bisschoppinck, P., 1998. Untersuchungen zur Transportmortalität beim Import von Vögeln und Reptilien nach Deutschland - mit einer Studie zu den Prä-Export-Bedingungen in Tansania. BfN (eds.), Bonn.

Stuart, B., Rhodin, A., Grismer, L., Hansel, T., 2006. Scientific description can imperil species. Science 312, 1137. http://dx.doi.org/10.1126/science.312.5777.1137b.

Stuart, B.L., Parham, J.F., 2007. Recent hybrid origin of three rare Chinese turtles. Conserv. Genet. 8, 169-175 (http://eprints.cdlib.org/uc/item/7fg1h86p).

Stoner, S.S., Nijman, V., 2015. The case for CITES Appendix I-listing of earless monitor lizards Lanthanotus borneensis. TRAFFIC Bull. 27, 55-58.

Sy, E., Brown, R., Afuang, L., Gonzalez, J.C., 2009. Trimeresurus mcgregori. The IUCN Red List of Threatened Species 2009: e.T169876A6685177 http://dx.doi.org/10.2305/IUCN. UK.2009-2.RLTS.T169876A6685177 (en - accessed 22 March 2016).

Sy, E.Y., 2012. First record of Varanus bitatawa in the Philippine pet trade. Biawak 6, 73.

Sy, E.Y., 2014. Siebenrockiella leytensis (Philippine forest turtle): artificial incubation and hatchling size. Herpetol. Rev. 45, 454-455.

Sy, E.Y., 2015. Turtles and Tortoises in the Philippine Pet Trade. Red Rhino Publishing, Manila.

Taylor, E.H., 1920. Philippine turtles. Philipp. J. Sci. 16, 111-144.

Todd, M., 2011. Trade in Malagasy Reptiles and Amphibians in Thailand. TRAFFIC Southeast Asia, Selangor.

Tolley, K., Menegon, M., 2014. Rhampholeon spinosus. The IUCN Red List of Threatened Species 2014: e.T176323A47652913 http://dx.doi.org/10.2305/IUCN.UK.2014-3. RLTS.T176323A47652913.en.

TRAFFIC, 2008. What's driving the wildlife trade? A review of expert opinion on economic and social drivers of the wildlife trade and trade control efforts in Cambodia, Indonesia, Lao PDR and Vietnam. East Asia and Pacific Region Sustainable Development Department. World Bank, Washington, DC.

TRAFFIC, 2014. TRAFFIC - wildlife trade. Available from http://www.traffic.org/trade/ (accessed 16 November 2014).

TRAFFIC, 2015. Thousands of critically endangered Palawan forest turtles seized. Press release 26th June. http://www.traffic.org/home/2015/6/24/thousands-of-criticallyendangered-palawan-forest-turtles-se.html.

Tuniyev, B., Nilson, G., Agasyan, A., Orlov, N., Tuniyev, S., 2009a. Vipera orlovi. The IUCN Red List of Threatened Species 2009: e.T164756A5923491 http://dx.doi. org/10.2305/IUCN.UK.2009.RLTS.T164756A5923491.en (accessed 12 November 2015).

Tuniyev, B., Nilson, G., Agasyan, A., Orlov, N., Tuniyev, S., 2009b. Vipera kaznakovi. The IUCN Red List of Threatened Species 2009: e.T22990A9405808 http://dx.doi.org/10. 2305/IUCN.UK.2009.RLTS.T22990A9405808.en (accessed 15 November 2015).

Turner, A.A., De Villiers, A.L., Hofmeyr, M.D., 2012. Reptiles. In: Turner, A.A. (Ed.), Western Cape Province State of Biodiversity 2012. CapeNature Scientific Services, Stellenbosch.

Uetz, P., Hošek, J. (Eds.), 2015. The Reptile Database (http://www.reptile-database.org accessed 13 August 2015)

UNEP-WCMC, 2010. Review of Species/Country Combinations Subject to Long-Standing Import Suspensions: Reptile Species from Africa. UNEP-WCMC, Cambridge.

UNEP-WCMC, 2015. CITES trade data for Uromastyx thomasi and Uromastyx princeps. http://trade.cites.org (accessed 18 September 2015). van Schingen, M., Pham, C.T. Thi, H.A., Bernardes, M., Hecht, V., et al, 2014 Current status of the crocodile lizard Shinisaurus crocodilurus Ahl, 1930 in Vietnam with implications for conservation measures. Rev. Suisse Zool. 121, 1-15.

van Schingen, M., Schepp, U., Pham, C.T., Nguyen, T.Q., Ziegler, T., 2015. Last chance to see? Review on the threats to and use of the crocodile lizard. TRAFFIC Bull. 27, 19-26.

van Schingen, M., Ha, Q.Q., Pham, C.T., Le, T.Q., Nguyen, Q.T., et al., 2016. Discovery of a new population of the crocodile lizard in Vietnam, population trends, future prognoses and identification of key habitats for conservation. Rev. Suisse Zool. (in press).

Velo-Antón, G., Wink, M., Schneeweiss, N., Fritz, U., 2011. Native or not? Tracing the origin of wild-caught and captive freshwater turtles in a threatened and widely distributed species (Emys orbicularis). Conserv. Genet. 12, 583-588. http://dx.doi.org/10.1007/ 10592-010-0145-5.

Vinke, T., Vinke, S., 2010. Do breeding facilities for chelonians threaten their stability in the wild? Schildkröten Im Fokus Online Vol. 7 pp. 1-18

Vinke, T., Vinke, S., 2015. May Illegal Be Legal within the European Union? Schildkröten Im Fokus Online, Bergheim Vol. 1 pp. 1-6 (http://www.schildkroeten-im-fokus.de/ pdf/2015_1vinke_en.pdf)

Warner, J.K., 2009. Conservation Biology of the Gaboon Adder (Bitis gabonica) in South Africa (Dissertation thesis) School of Animal, Plant and Environmental Sciences. University of the Witwatersrand, Johannesburg.

Webb, J.K., Brook, B.W., Shine, R., 2002. Collectors endanger Australia's most threatened snake, the broad-headed snake Hoplocephalus bungaroides. Oryx 36, 170-181.

Welton, L.J., Siler, C.D., Bennet, D., Diesmos, A.C., Duya, M.R., et al., 2010. A spectacular new Philippine monitor lizard reveals a hidden biogeographic boundary and a novel flagship species for conservation. Biol. Lett. 6, 654-658.

Wilson, L.D., Cruz Diaz, G., 1993. The herpetofauna of the Cayos Cochinos, Honduras. Herpetol. Nat. Hist. 1, 13-23.

Wyatt, T. 2013. A comparative analysis of wildlife trafficking in Australia, New Zealand, and the United Kingdom. Transnational Environmental Crime Project, Working Paper 6/2013. Australian National University, Canberra, Australia.

Wyler, L., Sheikh, P., 2013. International illegal trade in wildlife: threats and US policy. CRS Report for Congress. Congressional Research Service, US Congress, Washington DC.

Yaap, B., Paoli, G.D., Angki, A., Wells, P.L., Wahyudi, D., Auliya, M., 2012. First record of the Borneo earless monitor Lanthanotus borneensis (Steindachner, 1877) (Reptilia: Lanthanotidae) in West Kalimantan (Indonesian Borneo). J. Threat. Taxa 4, 3067-3074. http://dx.doi.org/10.11609/JoTT.03055.3067-74.

Yang, J.-H., Chan, B.P.-L., 2015. Two new species of the genus Goniurosaurus (Squamata: Sauria: Eublepharidae) from southern China. Zootaxa 3980, 067-080.

Yasukawa, Y., Ota, H., 2008. Geoemyda japonica Fan 1931 - Ryukyu black-breasted leaf turtle, Okinawa black-breasted leaf turtle. In: Rhodin, A.G.J., Pritchard, P.C.H., van Dijk, P.P., Saumure, R.A., Buhlamnn, K.A., Iverson, J.B. (Eds.), Conservation Biology of Freshwater Turtles and Tortoises: A Compilation Project of the IUCN/SSC Tortoise and Freshwater Turtle Specialist Group. Chelonian Research Monographs Vol. 5, pp. 002.1-002.6. http://dx.doi.org/10.3854/crm.5.002.japonica.v1.2008 (http:// www.iucn-tftsg.org/cbftt).

Zazanashvili, N., Mallon, D. (Eds.), 2009. Status and protection of globally threatened species in the Caucasus. CEPF, WWF. Contour Ltd., Tbilisi.

Zhou, Z., Jiang, Z., 2008. Characteristics and risk assessment of international trade in tortoises and freshwater turtles in China. Chelonian Conserv. Biol. 7, 28-36 (August).

Zhou, T., Blanck, T., McCord, W.P., Li, P.P., 2008. Tracking Cuora mccordi (Ernst, 1988); the first record of its natural habitat; a re-description; with data on captive populations and its vulnerability. Hamadryad 32, 46-58. 